\title{
Waste heat recovery technologies for offshore platforms
}

\author{
Pierobon, Leonardo; Benato, Alberto ; Scolari, E.; Haglind, Fredrik; Stoppato, Anna
}

\section{Published in:}

Applied Energy

Link to article, DOI:

10.1016/j.apenergy.2014.08.109

Publication date:

2014

Document Version

Early version, also known as pre-print

Link back to DTU Orbit

Citation (APA):

Pierobon, L., Benato, A., Scolari, E., Haglind, F., \& Stoppato, A. (2014). Waste heat recovery technologies for offshore platforms. Applied Energy, 136, 228-241. https://doi.org/10.1016/j.apenergy.2014.08.109

\section{General rights}

Copyright and moral rights for the publications made accessible in the public portal are retained by the authors and/or other copyright owners and it is a condition of accessing publications that users recognise and abide by the legal requirements associated with these rights.

- Users may download and print one copy of any publication from the public portal for the purpose of private study or research.

- You may not further distribute the material or use it for any profit-making activity or commercial gain

- You may freely distribute the URL identifying the publication in the public portal

If you believe that this document breaches copyright please contact us providing details, and we will remove access to the work immediately and investigate your claim. 


\title{
Waste heat recovery technologies for offshore platforms
}

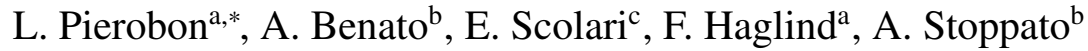 \\ ${ }^{a}$ Department of Mechanical Engineering, Technical University of Denmark \\ Building 403, 2800 Kongens Lyngby, Denmark \\ ${ }^{b}$ Department of Industrial Engineering, University of Padova \\ via Venezia 1, 35131 Padova, Italy \\ ${ }^{c}$ Department of Industrial Engineering, University of Bologna \\ viale Risorgimento 2, 40136 Bologna, Italy
}

\section{Abstract}

This article aims at finding the most suitable waste heat recovery technology for existing and future offshore facilities. The technologies considered in this work are the steam Rankine cycle, the air bottoming cycle and the organic Rankine cycle.

A multi-objective optimization approach is employed to attain optimal designs for each bottoming unit by selecting specific functions tailored to the oil and gas sector, i.e. yearly $\mathrm{CO}_{2}$ emissions, weight and economic revenue. The test case is the gas turbine-based power system serving an offshore platform in the North Sea.

Results indicate that the organic Rankine cycle technology presents larger performances compared to steam Rankine cycle units, whereas the implementation of air bottoming cycle modules is not attractive from an economic and environmental perspective compared to the other two technologies.

Despite the relatively high cost of the expander and of the primary heat exchanger, organic Rankine cycle turbogenerators appear thus to be the preferred solution to abate $\mathrm{CO}_{2}$ emissions and pollutants on oil and gas facilities.

As a practical consequence, this paper provides guidelines for the design of high-efficiency, cost-competitive and low-weight power systems for offshore installations.

Keywords: Offshore, Oil \& gas, Organic Rankine cycles, Waste heat, Optimization

\footnotetext{
${ }^{*}$ Corresponding author

Email address: lpier@mek.dtu.dk (L. Pierobon)
} 


\section{Introduction}

Owing to environmental concerns there is an urgent need to reduce greenhouse gas emissions and pollutants in the industrial, civil and transport sector. As reported by Nguyen et al. [1], the North Sea oil and gas platforms were responsible for about $25 \%$ of the total $\mathrm{CO}_{2}$ emissions of Norway in 2011. On offshore facilities the major contributor to the overall emissions is the power system which typically releases a large amount of heat to the environment [1]. Since 1991 Norway levies carbon tax on hydrocarbon fuels and the Norwegian government has recently increased the taxation by $200 \mathrm{NOK}(32 \$)$ per ton of $\mathrm{CO}_{2}$ in 2013 [2]. Thus, increasing the performance of power systems in offshore applications has become a focus area from an environmental and economic perspective. On oil and gas facilities one or more redundant gas turbines supply the electric power demand. As an example, a standard operational strategy is to share the load between two engines, while a third is on stand-by or on maintenance. The two gas turbines typically run at fairly low loads (around 50\%) in order to decrease the risk of failure of the system, which would cause a high economic loss to the platform operator. On the other hand, this operational strategy reduces significantly the system performance, which in turns results in a large amount of waste heat contained in the exhaust gases exiting the engines.

A viable solution to enhance the efficiency is to implement a waste heat recovery unit at the bottom of the gas turbines. Major design criteria are compactness, low weight and high reliability. A mature technology accomplishing these duties is the steam Rankine cycle (SRC). Kloster [3] described the existing SRC units in the Oseberg, Eldfisk and Snorre B offshore installations. Aiming at minimizing the weight of the heat transfer equipment, Nord and Bolland [4] suggested the use of SRC turbogenerators equipped with single-pressure once-through boilers (OTBs), instead of the heavier drum-type heat recovery steam generators. Air bottoming cycle (ABC) systems constitute a valid alternative to SRC units as they employ a non-toxic and inflammable working fluid. Moreover, $\mathrm{ABC}$ modules do not require a condenser as they operate as open-cycles, thus potentially leading to high compactness and low weight. Bolland et al. [5] performed a feasibility study on the implementation of ABCs offshore. Results proved that, despite the low gain in performance, low weight and short pay-back time are attained. Pierobon et al. [6] proposed instead 


\section{Nomenclature}

\begin{tabular}{|c|c|c|c|}
\hline$A$ & $\operatorname{area}\left[\mathrm{m}^{2}\right]$ & Abbreviations & \\
\hline$C_{\mathrm{T}}$ & turbine constant $\left[\mathrm{kg} \mathrm{K}^{0.5} \mathrm{~s}^{-1} \mathrm{bar}^{-1}\right]$ & $A B C$ & air bottoming cycle \\
\hline$F$ & factor in Equation B.6 & $A M A$ & arithmetic mean average \\
\hline$F_{\mathrm{cu}}$ & copper loss fraction & $D C$ & direct cost \\
\hline$F_{\mathrm{h}}, F_{\mathrm{p}}, F_{\mathrm{t}}, F_{\mathrm{l}}$ & fin height, pitch, thickness and length [mm] & $F P H E$ & finned-plate heat exchanger \\
\hline$G$ & mass flow velocity $\left[\mathrm{kg} \mathrm{m}^{-2} \mathrm{~s}^{-1}\right]$ & $I C$ & indirect cost \\
\hline$I_{\mathrm{CO} 2}$ & income saved $\mathrm{CO}_{2}$ emissions $\left[\$ \mathrm{yr}^{-1}\right]$ & $O R C$ & organic Rankine cycle \\
\hline$I_{\text {fuel }}$ & income saved fuel consumptions $\left[\$ \mathrm{yr}^{-1}\right]$ & $O T B$ & once-through boiler \\
\hline Load & electric generator load & $P E C$ & purchased-equipment cost \\
\hline$M_{\mathrm{f}}$ & maintenance factor & $R S D$ & relative standard deviation \\
\hline$N$ & rotational speed $\left[\mathrm{rad} \mathrm{s}^{-1}\right]$ & $S R C$ & steam Rankine cycle \\
\hline$N P V$ & net present value $[\$]$ & $T C I$ & total capital investment \\
\hline$N_{\mathrm{tp}}$ & number of tube passes & Greek letters & \\
\hline$N_{r}$ & average number of tubes in a vertical tube row & $\Delta$ & difference \\
\hline$N p$ & number of plates & $\eta$ & efficiency \\
\hline$N t$ & number of parallel tubes & $\gamma$ & exponent in Equation B.4 \\
\hline$N u, \operatorname{Pr}, \operatorname{Re}$ & Nusselt, Prandtl and Reynolds number & $\Gamma_{\mathrm{h}}$ & tube loading $\left[\mathrm{kg} \mathrm{m}^{-1} \mathrm{~s}^{-1}\right]$ \\
\hline$P$ & power $[\mathrm{kW}]$ & $\lambda$ & thermal conductivity $\left[\mathrm{W} \mathrm{m}{ }^{-1} \mathrm{~K}^{-1}\right]$ \\
\hline$P_{1}$ & longitudinal pitch $[\mathrm{m}]$ & $\mu$ & viscosity $\left[\mathrm{kg} \mathrm{m}^{-1} \mathrm{~s}^{-1}\right]$ \\
\hline$R_{c t}$ & thermal conduction resistance $\left[\mathrm{K} \mathrm{kW}^{-1}\right]$ & $\rho$ & density $\left[\mathrm{kg} \mathrm{m}^{-3}\right]$ \\
\hline$T$ & temperature $[\mathrm{K}]$ & $\xi$ & friction factor \\
\hline$U$ & overall heat transfer coefficient $\left[\mathrm{kW} \mathrm{m} \mathrm{K}^{-2} \mathrm{~K}^{-1}\right]$ & Subscripts & \\
\hline$W$ & weight $[\mathrm{kg}]$ & $a, e x h$ & air and exhaust gases \\
\hline$X$ & steam moisture content & $b$ & baffle \\
\hline $\bar{X}, \bar{J}$ & arrays of variables and of objective functions & $c$ & cold side, compressor or condenser \\
\hline$\dot{V}$ & volumetric flow rate $\left[\mathrm{m}^{3} \mathrm{~s}^{-1}\right]$ & des & design \\
\hline$\dot{m}$ & mass flow $\left[\mathrm{kg} \mathrm{s}^{-1}\right]$ & eco, eva, sup & economizer, evaporator and superheater \\
\hline$\dot{q}$ & heat rate $[\mathrm{kW}]$ & el & electric \\
\hline$c_{\mathrm{p}}$ & constant pressure heat capacity $\left[\mathrm{kJ} \mathrm{kg}^{-1} \mathrm{~K}^{-1}\right]$ & $f$ & fouling \\
\hline$d$ & diameter $[\mathrm{m}]$ & gen & generator \\
\hline$f, j$ & Fanning and Colburn factors & $h$ & hot side \\
\hline$h$ & heat transfer coefficient $\left[\mathrm{kW} \mathrm{m} \mathrm{m}^{-2} \mathrm{~K}^{-1}\right]$ or en- & $i$ & inner \\
\hline & thalpy $\left[\mathrm{kJ} \mathrm{kg}^{-1}\right]$ & in, out & inlet and outlet \\
\hline$i$ & discount rate & is & isentropic \\
\hline$l$ & length $[\mathrm{m}]$ & $l, v$ & liquid and vapour \\
\hline$m_{\mathrm{CO} 2}$ & $\mathrm{CO}_{2}$ emissions $\left[\right.$ ton $\left.\mathrm{d}^{-1}\right]$ & $\operatorname{lm}$ & logarithmic mean \\
\hline$n$ & number of stages or life-time [yr] & $p$ & pump \\
\hline$n f$ & number of fins per meter $\left[\mathrm{m}^{-1}\right]$ & $r$ & recuperator \\
\hline$p$ & pressure [bar] & $s h$ & shell-and-tube \\
\hline$r_{\mathrm{e}}, r_{\mathrm{c}}$ & expansion and compression ratios & $t$ & turbine or tube \\
\hline$u$ & velocity $\left[\mathrm{m} \mathrm{s}^{-1}\right]$ & wet & wet \\
\hline
\end{tabular}


the use of organic Rankine cycle (ORC) turbogenerators by tailoring their design to an exemplary oil and gas platform. The authors employed a multi-objective optimization approach to minimize the volume requirement, and, simultaneously, maximize the thermal efficiency and the economic revenue. As surveyed by Walnum et al. [7], supercritical $\mathrm{CO}_{2}$ power units may also be utilized to decrease the greenhouse emissions and pollutants as they exhibit high performances both at design- and part-load conditions. Mazzetti et al. [8] showed that combined cycle performances using a dual-stage supercritical $\mathrm{CO}_{2}$ bottoming unit are comparable with the values obtained with a SRC module. Furthermore, due to the high working pressure, the power module is expected to be extremely compact and light.

Notwithstanding the above-mentioned works, to the knowledge of the authors there is a lack in the literature of a comprehensive comparison among waste heat recovery technologies for offshore applications. In this context, this paper aims at finding the most suitable waste heat recovery unit to be implemented on existing and future oil and gas platforms. The multi-objective optimization coupled with the genetic algorithm is utilized to search for the optimal system designs (i.e. Pareto fronts) of each technology. The objective functions are the economic revenue, the weight of the bottoming cycle unit and the daily $\mathrm{CO}_{2}$ emissions. The detailed design of the heat transfer equipment and the material selection enable to include geometric quantities (e.g. tube length and tube diameter) among the optimization variables, thus allowing the estimation of the weight. Moreover, the implementation of part-load models within the optimization routine consents to evaluate the $\mathrm{CO}_{2}$ emissions over the entire year, and to estimate the profitability of the alternative investments. The case study is the power plant installed on an offshore oil and gas platform in the North Sea. The three power units considered in this work are the organic Rankine cycle, the steam Rankine cycle and the air bottoming cycle. Supercritical $\mathrm{CO}_{2}$ cycle configurations are not analysed here since such systems are still in the development phase.

This paper is structured as follows: Section 2 introduces the case study, while Section 3 describes the methodology utilized to perform the multi-objective design optimization. The results are then reported and discussed in Section 4. Concluding remarks are given in Section 5. 


\section{Case study}

The case study is the power system installed on the Draugen oil and gas offshore platform, located $150 \mathrm{~km}$ from Kristiansund, in the Norwegian Sea. The reservoir was discovered in 1984 and started operation in 1993. The platform, operated by A/S Norske Shell, produces gas exported via Åsgard gas pipeline to Kårst $\varnothing$ (Norway) and oil, which is first stored in tanks at the bottom of the sea and then shipped via a shuttle tanker (once every 1-2 weeks). Figure 1 shows the electric power demand, covered by three Siemens SGT500 gas turbines, on the platform in 2012. The non-dimensional values are reported with respect to the normal total electric load, equal to 19 MW. The power demand is increased up to $25 \mathrm{MW}$ during oil export. To enhance the reliability and diminish the risk of failure of the power system, two turbines run at a time covering $50 \%$ of the load each, while the third one is kept on stand-by, allowing for maintenance work. Despite the low performance, this strategy ensures the necessary reserve power for peak loads, and the safe operation of the engines. Table 1 lists the design-point specifications of the gas turbines as provided by the manufacturer. The twin-spool engine employs two coaxial shafts coupling the low pressure compressor (LPC) with the low pressure turbine (LPT) and the high pressure compressor (HPC) with the high pressure turbine (HPT). The power turbine (PT) transfers mechanical power through a dedicated shaft to the electric generator (GEN). Natural gas is the fuel utilized in the combustion chamber (CC).

Table 1: Design-point specifications for the twin-spool gas turbine installed on the Draugen offshore oil and gas platform.

Figure 2 shows the layout of the power system with the additional SRC unit recovering the heat contained in the exhaust gases produced by gas turbine A. Note that the bottoming cycle units should have the capability to harvest the waste heat alternatively from the other two engines, thus ensuring high performances when switching the gas turbines on operation. The SRC unit comprehends the single-pressure non-reheat once-through boiler (OTB), the steam turbine, the sea-water cooled shell-and-tube condenser and the feed-water pump. As surveyed by Nord and Bolland [4], this basic configuration consents to minimize the space requirement and the total weight. In Figure 3(a) the bottoming cycle unit is an ORC turbogenerator using cyclopentane 
Figure 1: Relative electric power demand on the Draugen offshore oil and gas platform in 2012. Daily average values are reported.

Figure 2: Simplified layout of the power system on the Draugen offshore oil and gas platform. The steam Rankine cycle module is added to recover part of the thermal power released with the exhaust gases of one engine, in the case gas turbine A.

(a)

as working fluid. This compound is widely adopted for operating ORC systems in this range of temperature, see e.g. Del Turco et al. [9]. The layout is similar to that of the SRC power module. As the slope of the saturation curve of cyclopentane is positive (dry fluid), a shell-andtube recuperator is added to decrease the energy contained in the superheated vapour exiting the ORC expander. Figure 3(b) depicts the combined plant configuration including the $\mathrm{ABC}$ unit. The air compressor (AC) sucks in ambient air, which is then heated up in the finned-plate heat exchanger (FPHE). As reported in Kays and London [10], this device offers higher performances and compactness for gas-to-gas heat transfer processes compared to shell-and-tube and flat-plate heat exchangers. The air then expands through the air turbine (AT) and the power air turbine (PAT), which drive the air compressor and the electric generator, respectively. The two-spool configuration is selected as it allows for higher part-load efficiencies compared to the single-spool arrangement [5]. Thermodynamic and transport properties of water, cyclopentane and air are calculated according to the models implemented in the open-source software developed by Bell et al. [11].

Figure 3: Combined cycle layouts, gas turbines B and $\mathrm{C}$ are also available but they are not shown in the sub-figures. 3(a) The organic Rankine cycle unit recovers part of the thermal power released with the exhausts of turbine A. 3(b) The air bottoming cycle module recuperates part of the thermal power released with the exhausts of turbine A. Although a wide variety of scenarios could be investigated, it was decided to split the load so that 
the combined cycle provides $14 \mathrm{MW}$ and gas turbine B supplies the remaining $5 \mathrm{MW}$. Note that for all the three technologies the combined cycle alone could potentially cover the entire base-load power demand with a higher efficiency. Nonetheless, this option is discarded since the necessary reserve power for peak loads would not be immediately available during normal operation and it would require the ignition of one of the gas turbines. Moreover, the proposed configuration does not compromise maintenance operations as the platform operator can decide to stop the gas turbine serving the combined cycle unit, and replace its function with one of the remaining engines.

\section{Methodology}

This section introduces first the procedures adopted for the thermodynamic cycle analysis of each bottoming unit (Section 3.1), and for the the heat transfer equipment design (Section 3.2). Subsequently, Sections 3.3 and 3.4 deal with the part-load modelling of the combined cycle components and with the control strategies assumed for the waste heat recovery systems. The economic analysis is then outlined in Section 3.5. Finally, Section 3.6 describes the simulation tool utilized to perform the design-point optimization.

\subsection{Thermodynamic state calculation}

The design-point analysis commences with the thermodynamic cycle calculation for the power modules illustrated in Figures 2, 3(a) and 3(b). Such step is accomplished by applying the first principle of Thermodynamics and the mass balance equation to each plant constituents, thus yielding the computation of the thermodynamic states at the inlet and outlet of each system component.
(a)
(b)
(c)

Figure 4: $T-s$ diagrams showing the thermodynamic cycle state points of one design candidate for each waste heat recovery technology. Isobar lines are also reported, pressure drops are neglected. 4(a) $T-s$ diagram and saturation dome (water) for the SRC turbogenerator. 4(b) $T-s$ diagram and saturation dome (cyclopentane) for the ORC power module. 4(c) $T-s$ diagram for the ABC unit.

For the sake of completeness, Figures 4(a), 4(b) and 4(c) illustrate the $T-s$ diagrams of one design candidate for each waste heat recovery technology obtained by applying the multi- 
objective optimization approach (see Section 4). The nodes where the working fluid is in saturated conditions, i.e. nodes 3 and 4 in Figure 4(a) and 4, 5 and 9 in Figure 4(b), are not reported in the plant layouts as evaporation and condensation start inside the once-through boiler and the shelland-tube condenser, respectively. As liquid droplets deteriorate the performance of the latter steam turbine stages (see point 6 in Figure 4(a)), the design-point isentropic efficiency $\eta_{\text {ist }}$ is penalized employing a correction factor expressed as a function of the steam moisture content $X_{6}$ at the turbine outlet (see Cotton [12]). The wet isentropic efficiency $\eta_{\text {is,t,wet }}$ is thus expressed as

$$
\begin{cases}\eta_{\mathrm{is}, \mathrm{twet}}=\eta_{\mathrm{is}, \mathrm{t}}-2\left(1-X_{6}\right), & 0.984<X_{6}<1.0, \\ \eta_{\mathrm{is}, \mathrm{tw} \mathrm{wet}}=\eta_{\mathrm{is}, \mathrm{t}}-0.032-0.76\left[1-\left(X_{6}+0.016\right)\right], & X_{6} \leq 0.984\end{cases}
$$

For energy balance calculations involving the exhaust gases, a constant pressure specific heat capacity of $1100 \mathrm{~J} \mathrm{~kg}^{-1} \mathrm{~K}^{-1}$ is used. Design-point temperature and mass flow of the exhaust stream exiting the gas turbine are $379.2^{\circ} \mathrm{C}$ and $91.5 \mathrm{~kg} \mathrm{~s}^{-1}$ (see Table 1).

\subsection{Heat transfer equipment}

The heat exchanger design procedure requires determining the surface area $A$ by evaluating, through an iterative procedure, the overall heat transfer coefficient $U$, which at hands reads

$$
\frac{1}{U A}=\frac{1}{h_{\mathrm{c}} A_{\mathrm{c}}}+\frac{1}{h_{\mathrm{f}, \mathrm{c}} A_{\mathrm{c}}}+R_{\mathrm{ct}}+\frac{1}{h_{\mathrm{h}} A_{\mathrm{h}}}+\frac{1}{h_{\mathrm{f}, \mathrm{h}} A_{\mathrm{h}}},
$$

where $h$ is fluid film coefficient, and $R_{\mathrm{ct}}$ is the thermal conduction resistance. The subscripts "c" and "h" stand for the cold and the hot side, while "f" refers to the fouling factor. Well-documented standardized procedures are adopted for the design of the heat transfer equipment, thus relating geometric quantities such as tube diameter and tube length to the coefficients given in Equation 2. Namely, the once-through boiler is modelled following the methodology suggested by Dumont and Heyen [13], the shell-and-tube heat exchanger with the approach reported in Coulson et al. [14] and the finned-plate heat exchanger using the procedure utilized by Yousefi et al. [15]. 
Figure 5: Layout of the once-through boiler serving the steam Rankine cycle and the organic Rankine cycle power units. The exhaust gases exiting the gas turbine heat up the working fluid (water or cyclopentane) which circulates first inside the preheater-evaporator, and, subsequently, in the superheater.

Regarding the once-through boiler (see Figure 5) installed on the SRC and ORC units, due the high thermal resistance of the exhaust gases flowing outside the tubes, finned tubes are employed to enhance the heat transfer coefficient $h_{\mathrm{h}}$. This is modelled by replacing the heat transfer and the fouling coefficients on the hot side in Equation (2) with a term involving fin area and effectiveness.

For sub-cooled liquid and superheated vapour the heat transfer coefficient inside the tubes is assessed with the correlations proposed by Gnielinski [16]. The heat transfer coefficient in the twophase region is evaluated by discretizing the tubes into finite segments (50 elements are adopted) and applying the method proposed by Shah [17], adapted for horizontal tubes. The gas-side heat transfer coefficient is computed using the approach proposed by Verein Deutscher Ingenieure [18], originally derived for air in circular finned-tube heat exchangers. The total pressure drops during evaporation are divided into three contributions: the static one, vanishing for the proposed configuration of horizontal tubes, the kinematic one, and the one due to viscous friction. The last two terms are evaluated according to the equations proposed by Friedel [19] and Rouhani and Axelsson [20], respectively. For the pressure drops on the gas side the correlation given by Haaf [21] is adopted. The equation is valid for banks of tubes in cross flow, with plain transverse fins, and it can be used for both staggered and in-line arrangement. As regards the transport properties of the exhaust gases, a thermal conductivity of $0.0463 \mathrm{~W} \mathrm{~m}^{-1} \mathrm{~K}^{-1}$ and a density of $0.5763 \mathrm{~kg} \mathrm{~m}^{-3}$ are assumed.

Figure 6: Layout of the shell-and-tube heat exchanger used for the condensation process and as recuperator in the organic Rankine cycle module. 6(a) Tube arrangement and shell flow pattern. 6(b) Triangular tube pattern.

The condenser and the recuperator are considered to be of the shell-and-tube type (see Figures 6(a) and 6(b)). The tubes of the recuperator are equipped with fins to enhance the heat transfer coefficient on the shell side, where the fluid is in the superheated vapour state. The Nusselt number 
on the shell side is calculated using the equation reported in Coulson et al. [14].

As condensation occurs in both single- and two-phase region, the condenser model utilizes two distinct correlations. The approach reported in Coulson et al. [14] is adopted for the superheated vapour section while the heat transfer coefficient during condensation is computed as suggested by Kern [22]. The sea-water heat transfer coefficient (tube side) is evaluated with the correlations proposed by Gnielinski [16]. The pressure drops in the single-phase regions are estimated according to Coulson et al. [14] while those on the condensing side are derived using the method proposed by Kern [22].

(a)

(b)

Figure 7: Layout of the finned-plate heat exchanger serving the air bottoming cycle power unit. 7(a) Exhaust gas and air flow pattern. 7(b) Finned-plate pattern.

The heat transfer coefficient on each side of the finned-plate heat exchanger (see Figures 7(a) and 7(b)) is calculated in accordance to Manglik and Bergles [23]. Regarding the pressure drops' calculation, the approach reported in Yousefi et al. [15] is utilized.

The design models of the shell-and-tube heat exchanger, of the FPHE and of the once-through boiler were validated by comparison with examples outlined in Coulson et al. [14], Yousefi et al. [15] and Dumont and Heyen [13], respectively. The differences between the models' results and the data reported in the references are within $4 \%$ in terms of both overall heat transfer coefficient and pressure drops.

Detailed list of equations for the estimation of the heat transfer coefficients and pressure drops of all heat exchangers modelled in this work are included in Appendix A.

\subsection{Part-load modelling}

The assessment of the part-load performance of the power systems introduced in Section 2 constitutes the first step towards the evaluation of the total yearly $\mathrm{CO}_{2}$ emission, thus enabling to determine the economic feasibility of the alternative investments. The gas turbines are modelled using the data provided by the manufacturer covering the entire operating range of the engines $(10 \%$ to $100 \%)$. The numerical data were replaced by interpolating functions selected to ensure a 
compromise between computational cost and accuracy. The equations provide the fuel consumption, the temperature and the mass flow of the exhaust gases as a function of the engine load at a constant ambient temperature $\left(15^{\circ} \mathrm{C}\right)$ and pressure $(1.032$ bar). The coefficient of determination, measuring the discrepancy between interpolating curves and data points, is higher than $99.0 \%$ for all functions. The gas turbine is thus considered as a black box, where the thermodynamic and transport properties of the exhaust stream serve as inputs to the part-load model describing the bottoming cycle unit.

For the once-through boiler, the ORC recuperator and the finned-plate heat exchanger the heat transfer coefficients of the cold and hot side, in off-design conditions, are evaluated with the relation proposed in Incropera et al. [24]. In the case of the once-through boiler and the shell-and-tube recuperator, the heat transfer resistance between the gas and the outer pipe surface is the dominant term, see Equation 2. Therefore, the conductive term and the heat transfer resistance of the cold stream are neglected when performing part-load simulations. The condenser is trivially modelled as a fixed pressure component. This is justified considering the large availability of cooling seawater, which allows the cooling circuit to be controlled in such a way that the condenser pressure is nearly constant. For all heat exchangers the pressure drops are lumped at the inlet of each heat exchanger and are evaluated assuming a quadratic dependence with the volumetric flow rate.

The air compressor is modelled by employing the maps of axial compressors provided with the commercial software developed by Kurzke [25]. These maps are represented by tables stating values for reduced flow, pressure ratio, isentropic efficiency and speed of revolution for the complete operating range of the component. Following the methodology proposed in Kurzke [26], the maps are scaled so that they can represent the part-load characteristic of the compressor serving the $\mathrm{ABC}$ unit.

For the turbines the Stodola's cone law, expressing the relation between the pressure at the inlet and at the outlet of the expander with the mass flow rate and the turbine inlet temperature is employed [27]. The Stodola's equation relies on the hypothesis that the working fluid is an ideal gas. Preliminary calculations showed that the compressibility factor during the expansion process presented an average value of 0.9 for cyclopentane and 0.95 for water, thus confirming the validity of the aforementioned assumption. To predict the turbines off-design performance, the correlation 
relating the isentropic efficiency and the non-dimensional flow coefficient proposed by Schobeiri [28] is utilized.

The isentropic efficiency of the ORC and SRC pumps in part-load is derived using the methodology proposed by Veres [29], while the part-load characteristic of the electric generator is modelled using the equation suggested by Haglind and Elmegaard [30].

Full list of equations describing the off-design performance of the components constituting the bottoming cycle units is reported in Appendix B.

\subsection{Control strategies}

The combined cycle part-load characteristic depends on the control strategy adopted for the topping unit and the waste heat recovery system. Unlike on-shore conventional combined cycle power plants, the SGT500 compressors are not equipped with variable inlet guide vanes, and the engine load can only be controlled by opening/closing the fuel valve. As a consequence, the exhaust temperature drops down for decreasing loads. Considering this, it is decided to operate the SRC and ORC power modules with the sliding-pressure mode. The evaporating pressure is governed by the Stodola's cone law and the rotational speed of the pump can be regulated with a variable frequency electric motor to maintain, for instance, a constant turbine inlet temperature (see Casella et al. [31]). This control strategy is selected for the ORC power module, while for the SRC unit it is decided to maintain a constant superheating approach temperature difference. Owing to the different thermodynamic properties of the working fluids (i.e. water and cyclopentane), the SRC turbogenerator enables to achieve higher turbine inlet temperatures compared to those of the ORC power module (see Figures 4(a) and 4(b)). Hence, operating the SRC turbogenerator at fixed turbine inlet temperatures results in an infeasible heat transfer process (i.e. negative superheating approach temperature difference) at a combined cycle load where the exhaust gas temperature exiting the gas turbine approaches the steam turbine inlet temperature.

As far as the air bottoming cycle unit is concerned, the pressure ratio and the rotational speed of the air compressor diminish with the load as a results of the interaction between the Stodola's equations and the compressor maps. The system does not present any degree of freedom and no operational strategy can be adopted. Preliminary calculations indicated that, for all the three 

rect costs (IC), thus allowing the estimation of the total capital investment. Table 2 shows the

technologies, the temperatures of the exhaust gases exiting the once-through boiler and the finnedplate heat exchanger do not vary significantly with the combined cycle load. Hence, corrosion problems caused by the condensation of sulphuric acid vapour are avoided.

\subsection{Economic analysis}

A feasibility study based on economic criteria requires first to estimate the total capital investment (TCI), and, secondly, to compute the total revenue of such investment. The first step is accomplished by following the methodology described in Bejan and Moran [32]. The procedure starts by evaluating the purchased-equipment cost (PEC) of the components constituting the bottoming cycle unit, and, subsequently, by incorporating the other direct costs (DC) and indi-

Table 2: Breakdown of the total capital investment.

breakdown of the total capital investment. The off-site costs are not considered as the installation of bottoming cycle units offshore does not require additional expenses related to the land and auxiliary facilities (e.g. fuel supply).

The purchased-equipment costs of the once-through boiler, the air compressor and the air turbines are acquired from Valero et al. [33]. The price of the pumps serving the SRC and the ORC power units and the cost of the electric generators are obtained from Lozano et al. [34] and Lian et al. [35], respectively. For the shell-and-tube heat exchangers and for the FPHE, the cost is related to the heat transfer area using the equations reported in Hall et al. [36] and Genceli [37].

The ORC and SRC turbines considered in this work provide a similar range of power (MWsize). Nevertheless, the thermo-physical properties of the working fluids play a key role on determining the final design, thus influencing the final cost. Consequently, the purchased-equipment cost of ORC expander is evaluated using the expression recently proposed by Astolfi et al. [38], which has been specifically developed for multi-stage axial turbines employing organic vapours as working fluid. The price of the steam turbine is determined with the correlation reported in Lozano et al. [34]. As the expressions for the components' cost evaluation, enclosed in Appendix 
1 C, derive from different sources, the PECs are adjusted for the same reference year (2014) using 2 the historical price indexes reported in Table 3 [39].

Table 3: Inflation index factors for the calculation of the purchased-equipment costs. The reference price index is 233.916 (2014).

The profitability evaluation is carried out using the net present value (NPV) method, see Bejan 4 and Moran [32]. The bottoming cycle unit yielding the highest NPV is deemed to be optimal 5 from an economic perspective. The net present value equation specific to the three power systems 6 described in Section 2 at hands reads

$$
N P V=\sum_{z=1}^{n} M_{\mathrm{f}}\left(I_{\mathrm{CO} 2}+I_{\mathrm{fuel}}\right) /(1+i)^{z}-T C I,
$$

7

where $I_{\mathrm{CO} 2}$ and $I_{\text {fuel }}$ are the yearly incomes associated to the avoided $\mathrm{CO}_{2}$ emissions and the fuel saving. Based on information provided by the platform operator, reasonable figures for the discount rate $i$ and the life-time of the investment $n$ are $6 \%$ and 20 years. So as to account for the operating and maintenance costs, the factor $M_{f}$ is set equal to 0.9 [35]. The incomes are assessed by computing first the difference in the yearly fuel consumption between the existing power system constituted of two gas turbines providing $50 \%$ load each and the plant comprising the combined cycle unit and one gas turbine, see Figure 2. The part-load models introduced in Section 3.3 are utilized for this purpose. The approach assumes a constant electric power demand on the platform of $19 \mathrm{MW}$ for the entire year, see Figure 1. Subsequently, the $\mathrm{CO}_{2}$ emissions are computed by means of the fuel consumption assuming a conversion factor of $2.45 \mathrm{~kg}\left(\mathrm{CO}_{2}\right) \mathrm{kg}(\mathrm{fuel})^{-1}$, which was derived from operational data provided by the Draugen platform operator. A fuel price of $0.68 \mathrm{NOK}(\mathrm{St}) \mathrm{m}^{-3}[6]$ and a $\mathrm{CO}_{2}$ tax of $410 \mathrm{NOK} \operatorname{ton}\left(\mathrm{CO}_{2}\right)^{-1}[2]$ are considered.

\subsection{The DYNDES tool}

The DYNDES tool [40] is a simulation program which couples steady state and dynamic software models in order to provide an integrated tool for the optimal design of power systems, including dynamic criteria. It is the present result of ongoing collaboration between the Technical 
design-point optimization.

Figure 8: Architecture of the DYNDES design tool. The usage of the program is limited to the steady-state designpoint optimization. which at hand reads

$$
\bar{X}_{\mathrm{SRC}}=\left[p_{5}, \Delta T_{\mathrm{OTB}}, \Delta T_{\mathrm{c}}, T_{11}, d_{\mathrm{i}, \mathrm{OTB}}, d_{\mathrm{i}, \mathrm{OTB}, \text { sup }}, l_{\mathrm{OTB}}, N t_{\mathrm{OTB}}, d_{\mathrm{i}, \mathrm{c}}, l_{\mathrm{c}}, l_{\mathrm{b}, \mathrm{c}}\right],
$$

$$
\bar{X}_{\mathrm{ORC}}=\left[p_{6}, \Delta T_{\mathrm{r}}, \Delta T_{\mathrm{OTB}}, \Delta T_{\mathrm{c}}, T_{11}, d_{\mathrm{i}, \mathrm{OTB}}, d_{\mathrm{i}, \mathrm{OTB}, \text { sup }}, l_{\mathrm{OTB}}, N t_{\mathrm{OTB}}, d_{\mathrm{i}, \mathrm{r}}, l_{\mathrm{r}}, l_{\mathrm{b}, \mathrm{r}}, d_{\mathrm{i}, \mathrm{c}}, l_{\mathrm{c}}, l_{\mathrm{b}, \mathrm{c}}\right],
$$

$$
\bar{X}_{\mathrm{ABC}}=\left[r_{\mathrm{c}}, \Delta T_{\mathrm{FPHE}}, T_{11}, F_{\mathrm{h}, \mathrm{a}}, n f_{\mathrm{a}}, F_{\mathrm{l}, \mathrm{a}}, F_{\mathrm{h}, \mathrm{exh}}, n f_{\mathrm{exh}}, F_{\mathrm{l}, \mathrm{exh}}, N p_{\mathrm{exh}}, l_{\mathrm{exh}}\right],
$$

University of Denmark and the Delft University of Technology. The evaluation of the system dy-

Given one of the three power system configurations introduced in Section 2, the multi-objective

where $p_{6}$ and $p_{5}$ are the ORC and SRC turbine inlet pressures, $T_{11}$ is the outlet temperature of the exhaust gases, $\Delta T_{\mathrm{c}}$ is the minimum temperature difference in the condenser and $\Delta T_{\text {OTB }}$ is the temperature difference between the two streams in the once-through boiler, at the location where the working fluid is in saturated liquid condition. The variable $N t_{\text {Отв }}$ is the number of tubes in parallel, while $d_{\mathrm{i}, \text { Отв }}$ and $d_{\mathrm{i}, \text { ОТВ,sup }}$ are the tube diameters of the preheater-evaporator and of the superheater, respectively. The unknowns $\Delta T_{\mathrm{r}}, l_{\mathrm{b}}$ and $l$ refer to the minimum temperature difference in the recuperator, the baffle spacing (given as a percentage of the shell diameter) and the length of the tubes. The subscripts "OTB", " $r$ " and "c" refer to the once-through boiler, the recuperator 
Table 4: Lower and upper bound for the variables involved in the multi-objective optimization of the three power systems described in Section 2.

Table 5: Parameters assumed for the multi-objective optimization.

and the condenser. In Equation $6, r_{\mathrm{c}}$ is the pressure ratio of the air compressor and $\Delta T_{\mathrm{FPHE}}$ is the temperature difference at the inlet of the FPHE. The variables $F_{\mathrm{h}}, n f, F_{1}$ and $N p$ are the fin height, the number of fins per meter, the fin length and the number of plates of the finned-plate heat exchanger. The subscripts "a" and "exh" refer to the air and the exhaust stream side.

The array of the objective functions $\bar{J}$ assumed in the present work is

$$
\bar{J}=\left[m_{\mathrm{CO} 2}, W, N P V\right],
$$

where $m_{\mathrm{CO} 2}$ are the average daily $\mathrm{CO}_{2}$ emissions of the power system being investigated (see Section 2), and the second metric accounts for the total bottoming cycle module weight determined summing the weights of the heat exchangers. The latter function $N P V$ is the net present value calculated as described in Section 3.5.

The multi-objective optimization uses a controlled elitist genetic algorithm to find for solutions which optimize simultaneously the three objective functions. Compared to gradient-based methods, a genetic algorithm is less prone to end its search in local minima of the problem, usually converging towards global optima. This typically comes at the cost of an increased computational effort, due to the large number of evaluation of the objective functions [41]. The genetic algorithm parameters are specified as follows: population size 200, generation size 200, crossover fraction 0.8 , and migration fraction 0.2. These numerical values are selected so as to ensure the repeatability of the solution when different simulations are performed. 
operate on a wide range of both liquid and gas fuels, the terminal temperature of the exhaust gases exiting the once-through boiler has a lower limit of $140{ }^{\circ} \mathrm{C}$. Hence, the condensation of corrosive compounds, in the case that other fuels (crude oil, heavy fuel oil and naphtha) than natural gas are combusted, is prevented. As the present work does not deal with supercritical ORC power modules, the upper bound for the turbine inlet pressure is set equal to $90 \%$ of the critical pressure of cyclopentane.

Table 5 lists the parameters which are kept constant during the multi-objective optimization. The fin profile and the configuration of the once-through boiler, the shell-and-tube recuperator and the finned-plate heat exchanger are retrieved from Dumont and Heyen [13], Coulson et al. [14] and Yousefi et al. [15], respectively. The condensing pressure of the ORC unit is fixed to 1.03 bar so as to avoid infiltration of air inside the piping from the surroundings. The same condensing temperature (i.e. $50{ }^{\circ} \mathrm{C}$ ) is selected for the SRC module, corresponding to a pressure of 0.12 bar.

Referring to Figure 8, the optimizer solves a design-point problem determining the thermodynamic states at the inlet and at the outlet of the components constituting the bottoming cycle unit under investigation. The pressure drops in the heat exchangers are initially set to zero. At this point the design procedure of the heat transfer equipment (see Section 3.2) is started, obtaining as outputs both the pressure drops and the components' weight. The design-point solver is thus run again, considering the pressure losses in the heat exchangers. The results are then checked with respect to the first and second principle of Thermodynamics. Furthermore, it is verified that the velocity on the hot and cold side of the heat exchangers lays within the ranges specified in Coulson et al. [14]. A lower limit of $84 \%$ for the vapour quality at the steam turbine outlet must also be respected. If the test on the results is positive, the part-load simulation is performed using the models outlined in Section 3.3. Design-point constraints such as heat exchangers pinch points and turbine inlet pressures are replaced by U-values and Stodola's constants and the components' efficiency is a function of the operating conditions. In such way, the part-load solver computes the $\mathrm{CO}_{2}$ emissions, thus providing the inputs for the economic analysis. The process is repeated until the average change in the spread of the Pareto front is lower than the specified tolerance, which is assumed here equal to $10^{-3}$. 


\section{Results and discussion}

Table 6: Results of the multi-objective optimization. Maximum, minimum, arithmetic mean average, and relative standard deviation of the optimized variables. The values are acquired from the Pareto fronts of the waste heat recovery systems.

Figure 9: Pareto fronts of the three waste heat recovery technologies. The $\mathrm{CO}_{2}$ emissions (first objective function) are given as a function of the weight of the bottoming cycle units (second objective function).

Figure 10: Pareto fronts of the three waste heat recovery technologies. The net present value (third objective function) is related to the weight of the bottoming cycle units.

Table 6 lists the results of the multi-objective optimization procedure. The arithmetic mean average (AMA), the relative standard deviation (RSD) in percent, and the minimum and maximum values of the optimized variables are reported for the three waste heat recovery technologies. A low RSD means that the variable does not vary significantly with the optimal configurations of the waste heat recovery unit. The pinch point and the baffle length of the condensers, the temperature of the exhaust gases and the numbers of fins per meter of the FPHE present the lowest RSDs. As a practical implication, Table 6 provides to the designer figures for the optimal geometry of the heat transfer equipment. Hence, since the dimensions for heat exchangers are standardized, based on the optimal geometric variables (e.g. tube length) the designer can select the closest standardized values.

Figure 9 shows the two-dimensional prospect of the Pareto front relating the average daily $\mathrm{CO}_{2}$ emissions of the power systems with the weight of the corresponding bottoming cycle unit. The three curves present a hyperbolic trend. Increasing the heat transfer area (i.e. the weight) allows to recuperate more heat from the gas turbine exhaust stream, and to lower the heat transfer irreversibility in the heat exchangers, thus improving the performance of the combined cycle units. The power system employing the $\mathrm{ABC}$ unit presents the lowest yearly system performance (highest $\mathrm{CO}_{2}$ emissions), while it enables to achieve the lowest possible weight (30 ton). For weights between 40 and 50 ton, ORC and SRC units competes in terms of weight and efficiency, while the 
Figure 11: Breakdown of the weight for the three waste heat recovery technologies. The weight of the heat exchangers constituting the bottoming cycle units is reported.

Figure 12: Breakdown of the purchased-equipment cost for the three waste heat recovery technologies. The purchased-equipment cost of the components constituting the bottoming cycle units is indicated.

ORC unit is superior in respect of performances compared to both the SRC and ABC technology from 50 to 130 ton. It should be noticed that the steam Rankine cycle curve presents the narrowest Pareto front ranging from 266 to 268 ton $\mathrm{d}^{-1}$. Main reason limiting the applicability of SRC units is the deterioration of the turbine efficiency caused by the liquid content at the turbine outlet (see Section 3.1). Moreover, as explained in Section 3.6, the algorithm discards all design solutions which present a vapour quality lower than $84 \%$ at the inlet of the condenser since they will lead to unacceptable mechanical stresses on the blades constituting the latter turbine stages.

In Figure 10 the third objective function, i.e. net present value, is plotted as a function of the weight. For all three waste heat recovery systems the curves initially increase and subsequently flatten out. Since the net present value is a function of the total investment cost and the yearly incomes (dependent on the combined cycles performance), an optimum is reached. After this maximum, enhancing the performance of the bottoming cycle modules by increasing the weight diminishes the economic revenue since the total investment cost becomes excessively large. The implementation of the $\mathrm{ABC}$ unit does not appear to be economically attractive. In fact, the net present value is negative at low and high weights and the peak is 2-3 times lower than those of the ORC and SRC power modules. The highest economic revenue (0.5 M\$) occurs for a combined cycle power of $18.6 \mathrm{MW}$ with a design- and part-load efficiency of $35.1 \%$ and $31.9 \%$.

The waste heat recovery technology which allows to achieve the highest net present value $(3.7 \mathrm{M} \$$ ) is the steam Rankine cycle. For this solution the combined cycle power is $21.2 \mathrm{MW}$, and the thermal efficiencies at design- and part-load are $40.1 \%$ and $35.6 \%$. As regards the ORC technology, the highest economic revenue is obtained for a net power output of 21.3 MW while the design- and part-load efficiencies are $40.2 \%$ and $35.9 \%$. 
bottoming cycle units designed using the set of variables giving the highest the net present value. The weight of the ORC and SRC power modules is primarily determined by the once-through boiler where stainless steel finned tubes are utilized to cope with the high heat transfer resistance of the exhaust gas stream. The water-cooled condensers and the ORC recuperator contribute with around 20 ton each to the total weight. The heat transfer equipment serving the $\mathrm{ABC}$ unit consists only of the finned-plate heat exchanger with a weight of 54 ton. Although an accurate weight calculation of the turbomachinery serving the bottoming cycle units is presently beyond the capability of the developed models, proprietary information made available by ORC manufacturers indicates that the contribution of the package comprising the turbine and the electric generator is typically around $30 \%$ of the weight of the heat transfer equipment. While the same share is to be expected for the SRC unit, figures for the turbomachinery in ABC modules are instead comparable with those of the finned-plate heat exchanger [5]. In light of such approximate quotations, the benefits of employing the $\mathrm{ABC}$ technology for low-weight power systems may diminish by virtue of the larger contribution of the turbomachinery compared to SRC and ORC modules.

Adopting the economic criterion, the ORC is the heaviest power module. Nevertheless, Figure 10 shows that for the ORC system the net present value does not vary significantly between 50 and 130 ton. Such trend may lead the plant designer to abate the total weight while maintaining the same economic revenue. Figure 12 indicates that the compressor and the two turbines contribute with the largest shares to the purchased-equipment cost of the $\mathrm{ABC}$ system. In the case of the SRC and the ORC units, the once-through boiler and the turbine are the most expensive components. Despite the lower daily $\mathrm{CO}_{2}$ emissions (i.e. higher combined cycle plant part-load performance), the ORC technology exhibits a lower economic revenue compared to the plant configuration including the SRC unit. In fact, the increased incomes related to the $\mathrm{CO}_{2}$ tax and fuel savings are not sufficient to justify the higher equipment expenses (see Figure 12).

Figure 10 evidences a more scattered trend for the net present value of the $\mathrm{ABC}$ unit compared to those of the ORC and SRC technologies. The different tendency originates from two reasons: i) the PEC of the air bottoming cycle unit is governed both by the compressor and the two turbines while the cost of the SRC and ORC modules primarily relates to the expander (see Figure 12), ii) the expressions employed to evaluate the purchased-equipment cost of the turbines and the 
compressor are a transcendental function of both mass flow and pressure ratio (see Appendix C)

The results obtained in this paper are derived using various correlations, all of which are associated with uncertainties. The assumptions that have the largest influence on the results are the equations utilized to estimate the heat transfer coefficients and the purchased-equipment cost of the components constituting the three bottoming cycle units. As en example, in evaluating heat transfer coefficients, average variations of $15 \%-20 \%$ and maximum deviations of about $40 \%$ are to be expected [42], thus influencing the weight calculation. Moreover, precise correlations relating the purchased-equipment cost of plant components to design variables and parameters are of paramount importance for an accurate economic analysis. Due to the lack of public available equations characterizing the purchased-equipment costs of all the components considered in this work, generic correlations were adopted, thus resulting in a certain degree of uncertainty. Considering all these aspects, the results of the weight calculation and of the economic study have been utilized to carry out a qualitative comparison of the different waste heat recovery technologies. Nevertheless, preliminary investigations proved that the numerical results hold quantitatively true as the weight and the total investment cost per unit of power are within the range of values reported in Nord and Bolland [4] and Boyce [43] for the SRC power unit, in Bolland et al. [5] for the ABC system and in Pierobon et al. [44] and [45] for the ORC power modules.

\section{Conclusions}

The multi-objective optimization approach presented in this work enabled to compare the use of steam Rankine cycle, organic Rankine cycle and air bottoming cycle power modules to enhance the efficiency of existing and future offshore installations. The performance metrics are the average daily $\mathrm{CO}_{2}$ emissions, the weight and the economic revenue. The methodology is applied to recover part of the waste heat from the gas turbines-based power system of an offshore oil and gas platform.

The organic Rankine cycle technology exhibits the highest yearly system performance, thus enabling to abate $\mathrm{CO}_{2}$ emissions and pollutants. The combined cycle design-point and part-load thermal efficiencies are $0.2 \%$-points and $5.1 \%$-points higher compared to the use of the steam Rankine cycle and air bottoming cycle systems. The steam Rankine cycle technology appears to be favourable from an economic perspective as it consents to achieve the highest net present 
value (3.7 M\$). Moreover, the results indicate that the use of $\mathrm{ABC}$ power modules is not attractive from an economic and environmental perspective compared to the other two technologies. For all three bottoming cycle units the heat exchanger harvesting the exhaust gases heat is the heaviest component, while the turbines contribute with the largest share to the total cost of the system.

It can be concluded that the steam Rankine cycle and the organic Rankine cycle are competing technologies when targeting at the design of highly-efficient offshore platforms. Advantages in terms of applicability range and system performance seem to lean toward the use of organic Rankine cycle turbogenerators although investment costs have to be reduced to enhance the economic revenue. The implementation of air bottoming cycle units offshore does not appear to be convenient from a performance and economic perspective.

\section{Acknowledgements}

The funding from the Norwegian Research Council through Petromaks with project number 203404/E30 is acknowledged. We also acknowledge the kind support from Siemens Industrial Turbomachinery AB, Finspång, Sweden for providing the necessary technical documentation. The authors also thank the former master's students Julie Uhrbrand and Rikke Aavang Andersen, who helped developing the first version of the finned-plate heat exchanger model utilized in this paper.

\section{Appendix A. Heat transfer and pressure drop correlations}

In this appendix we report the correlations utilized to evaluate the heat transfer coefficients and the pressure drops of the heat exchangers (see Section 3.2). For the gas side and single-phase flow the correlations at hand reads

- Gas flow outside finned tubes (Verein Deutscher Ingenieure [18] and Haaf [21])

$$
\begin{gathered}
N u=0.22 \operatorname{Re}^{0.6} \operatorname{Pr}^{1 / 3}\left(A / A_{\mathrm{t}}\right)^{-0.15}, \\
\Delta p=2.5 N_{\mathrm{tp}} \operatorname{Re}^{-1 / 4}\left(P_{1} / d\right)^{0.4} \rho u^{2} / 2,
\end{gathered}
$$


where $A_{\mathrm{t}}$ is the outside surface area of the tube considering fins, $P_{1}$ is the longitudinal pitch, $N_{\text {tp }}$ is the number of tube passes, $\rho$ is the fluid density and $u$ is the fluid velocity. The variables $\mathrm{Nu}, \mathrm{Pr}$ and $\mathrm{Re}$ are the Nusselt number, the Prandtl number and the Reynolds number.

- Single-phase flow (Gnielinski [16] and Coulson et al. [14])

$$
\left\{\begin{array}{c}
N u=\frac{(\xi / 8)(\operatorname{Re}-1000) P r}{1+12.7 \sqrt{(\xi / 8)}\left(\operatorname{Pr}^{2 / 3}-1\right)}\left[1+\left(\frac{d}{l}\right)^{2 / 3}\right], \\
\xi=1.84 \log _{10} \operatorname{Re}-1.64 \\
\Delta p=N_{\mathrm{tp}}\left(8 \xi \frac{l}{d}+2.5\right) \rho u^{2} / 2,
\end{array}\right.
$$

where $\xi$ is the friction factor.

Evaporation inside horizontal tubes is modelled implementing the list of equations reported in coefficient $h_{c}$ is expressed, in accordance to Kern [22], as

$$
h_{c}=0.95 \lambda_{1}\left[9.81 \rho_{1}\left(\rho_{1}-\rho_{\mathrm{v}}\right) /\left(\mu_{1} \Gamma_{\mathrm{h}}\right)\right]^{1 / 3} N_{\mathrm{r}}^{-1 / 6},
$$
detail in Shah [17] for the heat transfer coefficient and in Friedel [19] and in Rouhani and Axelsson [20] for the pressure drops. As regarding condensation outside horizontal tubes, the heat transfer

where $N_{\mathrm{r}}$ is the average number of tubes in a vertical tube row, $\Gamma_{\mathrm{h}}$ is the tube loading, $\lambda$ is the fluid thermal conductivity and $\mu$ is the fluid viscosity. The subscripts " $l$ " and " $v$ " refer to the saturated liquid and saturated vapour conditions. As suggested by Kern [22], the pressure drop are evaluated using the method for single-phase flow (see Equation A.4) and applying a factor of 50 per cent to allow for the change in vapour velocity.

The Nusselt number on the shell side of the recuperator equipped with finned tubes can be written as (see Coulson et al. [14]) 


$$
N u=0.134 \operatorname{Re}^{0.681} \operatorname{Pr}^{1 / 3}\left(\left(F_{\mathrm{p}}-F_{\mathrm{t}}\right) / F_{\mathrm{h}}\right)^{0.2}\left(F_{\mathrm{p}} / F_{\mathrm{t}}\right)^{0.1134},
$$
3

4 changer (see Figures 7(a) and 7(b)) are expressed as follows (see Manglik and Bergles [23])

$$
\begin{gathered}
h=j G c_{\mathrm{p}} \operatorname{Pr}^{-2 / 3}, \\
\Delta p=2(l / d) f G^{2} / \rho .
\end{gathered}
$$

6

- Turbines (Stodola [27] and Schobeiri [28])

$$
\begin{gathered}
C_{\mathrm{T}}=\frac{\dot{m} \sqrt{T_{\mathrm{in}}}}{\sqrt{{p_{\text {in }}^{2}-p_{\text {out }}^{2}}^{2}}}, \\
\eta_{\text {is }, \mathrm{t}}=\eta_{\text {is }, \mathrm{t}, \mathrm{des}} \frac{N}{N_{\mathrm{des}}} \sqrt{\frac{\Delta h_{\mathrm{is}, \mathrm{des}}}{\Delta h_{\mathrm{is}}}}\left(2-\frac{N}{N_{\mathrm{des}}} \sqrt{\frac{\Delta h_{\mathrm{is}, \mathrm{des}}}{\Delta h_{\mathrm{is}}}}\right) .
\end{gathered}
$$

In Equation B. $1 C_{\mathrm{T}}$ is the turbine constant, $\dot{m}$ is the mass flow, $T_{\text {in }}$ is turbine inlet temperature, $p_{\text {in }}$ and $p_{\text {out }}$ are the inlet and outlet pressures. In Equation B.2 the isentropic efficiency $\eta_{\text {is,t }}$ 
is given as a function of the rotational speed $N$ in rpm and the isentropic enthalpy drop $\Delta h_{\text {is }}$. The subscript "des" refers to the variable calculated at design-point.

- Electric generators (Haglind and Elmegaard [30])

$$
\eta_{\mathrm{el}}=\frac{\operatorname{Load} \eta_{\mathrm{el}, \mathrm{des}}}{\operatorname{Load} \eta_{\mathrm{el}, \mathrm{des}}+\left(1-\eta_{\mathrm{el}, \mathrm{des}}\right)\left[\left(1-F_{\mathrm{cu}}\right)+F_{\mathrm{cu}} \operatorname{Load}^{2}\right]},
$$

where $\eta_{\mathrm{el}}$ is the electric efficiency of the generator, Load is the mechanical power input in per unit and $F_{\mathrm{cu}}$ the copper loss fraction.

- Heat exchangers (Incropera et al. [24])

$$
\begin{gathered}
h=h_{\mathrm{des}}\left(\frac{\dot{m}}{\dot{m}_{\mathrm{des}}}\right)^{\gamma}, \\
\Delta p=\Delta p_{\mathrm{des}}\left(\frac{\dot{V}}{\dot{V}_{\mathrm{des}}}\right)^{2} .
\end{gathered}
$$

The exponent $\gamma$ is taken equal to 0.8 or 0.6 depending on the fluid location (inside or outside the tube banks). In Equation B.5 the variables $\dot{V}$ and $\Delta p$ are the volumetric flow rate and the pressure drop inside (outside) the tubes.

- Pumps (Veres [29])

$$
\begin{gathered}
\eta_{\mathrm{p}}=\eta_{\mathrm{p}, \mathrm{des}}\left(0.86387+0.3096 F-0.14086 F^{2}-0.029265 F^{3}\right), \\
F=\frac{\dot{V} / N}{\dot{V}_{\mathrm{des}} / N_{\mathrm{des}}},
\end{gathered}
$$

where $\eta_{\mathrm{p}}$ is the pump hydraulic efficiency. 


\section{Appendix C. Purchased-equipment cost}

This appendix lists the equations utilized to estimate the purchased-equipment cost of the com3 ponents constituting the three waste heat recovery technologies. The purchased-equipment costs

4 of the air compressor $P E C_{\mathrm{AC}}$ and of the air turbine $P E C_{\mathrm{AT}}$ are calculated as (see Valero et al. [33])

$$
\begin{gathered}
P E C_{\mathrm{AC}}=39.5 \dot{m}_{\mathrm{a}} \frac{r_{\mathrm{c}} \log \left(r_{\mathrm{c}}\right)}{0.9-\eta_{\mathrm{is}, \mathrm{c}}}, \\
P E C_{\mathrm{AT}}=266.3 \dot{m}_{\mathrm{a}} \frac{\log \left(r_{\mathrm{e}}\right)\left(1+\exp \left(0.036 T_{\mathrm{in}}-54.4\right)\right.}{0.92-\eta_{\mathrm{is}, \mathrm{t}}},
\end{gathered}
$$

5

$$
\begin{gathered}
P E C_{\mathrm{p}}=378\left[1+\left(\frac{1-0.808}{1-\eta_{\mathrm{p}}}\right)^{3}\right] P_{\mathrm{p}}^{0.71}, \\
P E C_{\mathrm{gen}}=60 P_{\mathrm{gen}}^{0.95},
\end{gathered}
$$

10

where $\dot{m}_{\mathrm{a}}$ and $r_{\mathrm{e}}$ are the air mass flow and the expansion ratio. The variable $\eta_{\mathrm{is}, \mathrm{c}}$ is the isentropic efficiency of the compressor. Equation C.2 applies also for the power air turbine.

The prices of the pumps $P E C_{\mathrm{p}}$ serving the SRC and the ORC power units and the cost of the electric generators $P E C_{\text {gen }}$ are computed as (see Lozano et al. [34] and Lian et al. [35])

where $P_{\mathrm{p}}$ and $P_{\text {gen }}$ are the pump and the electric power produced by the generator. While the purchased-equipment cost of the steam turbine is set as a function of the mechanical power output $P_{\mathrm{t}}$ in accordance with Lozano et al. [34], the cost of the ORC expander depends on the number of stages $n$ and the size parameter $\sqrt{\dot{V}_{7}} / \Delta h_{\text {is }}^{1 / 4}$ of the last stage (see Astolfi et al. [38]);

$$
\begin{gathered}
P E C_{\mathrm{t}, \mathrm{SRC}}=3000\left[1+5 \exp \left(\frac{T_{\mathrm{in}}-866}{10.42}\right)\right]\left[1+\left(\frac{1-0.953}{1-\eta_{\mathrm{is}, \mathrm{t}}}\right)^{3}\right] P_{\mathrm{t}}^{0.7}, \\
P E C_{\mathrm{t}, \mathrm{ORC}}=1600\left(\frac{n}{2}\right)^{0.5}\left(\frac{\sqrt{\dot{V}_{7}} / \Delta h_{\mathrm{is}}^{1 / 4}}{0.18}\right)^{1.1} .
\end{gathered}
$$




$$
\begin{gathered}
P E C_{\mathrm{OTB}}=3650\left[\left(\frac{\dot{q}_{\mathrm{eva}}}{\Delta T_{\mathrm{lm}, \mathrm{eva}}}\right)^{0.8}+\left(\frac{\dot{q}_{\mathrm{eco}}}{\Delta T_{\mathrm{lm}, \mathrm{eco}}}\right)^{0.8}\right]+11820 \dot{m}+658 \dot{m}_{\mathrm{exh}}^{1.2}, \\
P E C_{\mathrm{sh}}=30800+890 A_{\mathrm{sh}}^{0.81}, \\
P E C_{\mathrm{FPHE}}=187+25 A_{\mathrm{FPHE}},
\end{gathered}
$$

where $\dot{q}_{\text {eva }}$ and $\Delta T_{\text {lm,eva }}$ are the heat rate and the logarithmic mean temperature difference limited to the vapour-liquid region, while the variables $\dot{q}_{\text {eco }}$ and $\Delta T_{\text {lm,eco }}$ refer to the liquid-phase zone. The subscripts "OTB", "sh" and "FPHE" indicate the once-through boiler, the shell-and-tube heat exchanger and the finned-plate heat exchanger. The variables $\dot{m}_{\text {exh }}$ and $\dot{m}$ represent the mass flow of the exhaust gases and of the working fluid flowing inside the OTB tubes.

\section{References}

[1] Nguyen, T.V., Pierobon, L., Elmegaard, B., Haglind, F., Breuhaus, P., Voldsund, M.. Exergetic assessment of energy systems on North Sea oil and gas platforms. Energy 2013;62(0):23 - 36 .

[2] Ministry of the Environment, . The Government is following up on the Climate Agreement. www.regjeringen.no/en/dep/md/press-centre/press-releases/2012/the-government-is-following-up-on-thecl.html?id=704137 [accessed: 03/02/2014]. Norway 2013.

[3] Kloster, P.. Energy optimization on offshore installations with emphasis on offshore combined cycle plants. In: Offshore Europe Conference. Aberdeen, Great Britain: Society of Petroleum Engineers; 1999, p. 1-9.

[4] Nord, L.O., Bolland, O.. Steam bottoming cycles offshore-challenges and possibilities. Journal of Power Technologies 2012;92(3):201-207.

[5] Bolland, O., Forde, M., Hånde, B.. Air bottoming cycle: use of gas turbine waste heat for power generation. Journal of engineering for gas turbines and power 1996;118:359-368. 
[6] Pierobon, L., Nguyen, T.V., Larsen, U., Haglind, F., Elmegaard, B.. Multi-objective optimization of organic Rankine cycles for waste heat recovery: Application in an offshore platform. Energy 2013;58(0):538 - 549.

[7] Walnum, H.T., Neks, P., Nord, L.O., Andresen, T.. Modelling and simulation of $\mathrm{CO}_{2}$ (carbon dioxide) bottoming cycles for offshore oil and gas installations at design and off-design conditions. Energy 2013;59(0):513 -520 .

[8] Mazzetti, M., Nekså, P., Walnum, H.T., Hemmingsen, A.K.. Novel energy efficiency technologies for reduction of offshore $\mathrm{CO}_{2}$ emissions. In: Offshore Technology Conference. Houston, Texas: Offshore Technology Conference; 2013, p. 1339-1350.

[9] Del Turco, P., Asti, A., Del Greco, A., Bacci, A., Landi, G., Seghi, G.. The ORegen waste heat recovery cycle: Reducing the $\mathrm{CO}_{2}$ footprint by means of overall cycle efficiency improvement. In: Proceedings of ASME Turbo Expo 2011. Vancouver, Canada; 2011, p. 547-556.

[10] Kays, W.M., London, A.L.. Compact heat exchangers. New York, United States of America: McGraw-Hill; 1984. ISBN: 9780070333918.

[11] Bell, I.H., Wronski, J., Quoilin, S., Lemort, V.. Pure and pseudo-pure fluid thermophysical property evaluation and the open-source thermophysical property library CoolProp. Industrial \& Engineering Chemistry Research 2014;53(6):2498-2508.

[12] Cotton, K.C.. Evaluating and improving steam turbine performance. Rexford, United States of America: Cotton Fact; 1998. ISBN: 9780963995513.

[13] Dumont, M.N., Heyen, G.. Mathematical modelling and design of an advanced once-through heat recovery steam generator. Computers \& Chemical Engineering 2004;28(5):651 - 660.

[14] Coulson, J., Richardson, J., Backhurst, J.. Coulson and Richardson's Chemical Engineering. Chemical engineering; Oxford, Great Britain: Butterworth-Heinemann; 1999. ISBN: 9780750644440.

[15] Yousefi, M., Enayatifar, R., Darus, A.. Optimal design of plate-fin heat exchangers by a hybrid evolutionary algorithm. International Communications in Heat and Mass Transfer 2012;39(2):258 - 263.

[16] Gnielinski, V.. On heat transfer in tubes. International Journal of Heat and Mass Transfer 2013;63(0):134 140.

[17] Shah, M.. Chart correlation for saturated boiling heat transfer: equations and further study. ASHRAE Transaction 1982;88(1):185-196.

[18] Verein Deutscher Ingenieure, . VDI-Wärmeatlas: Berechnungsblätter für den Wärmeübergang. Berlin, Germany: Springer-Verlag; 1953. ISBN: 9783540412014.

[19] Friedel, L.. Pressure drop during gas/vapor-liquid flow in pipes. International Chemical Engineering 1980;20(3):352-367.

[20] Rouhani, S.Z., Axelsson, E.. Calculation of void volume fraction in the subcooled and quality boiling regions. International Journal of Heat and Mass Transfer 1970;13(2):383-393. 
[21] Haaf, S.. Wärmeübertragung in Luftkühlern. Berlin, Germany: Springer Verlag; 1988. ISBN: 9783540154778.

[22] Kern, D.Q.. Process heat transfer. New York, United States of America: McGraw-Hill; 1950. ISBN: 9780070341906.

[23] Manglik, R.M., Bergles, A.E.. Heat transfer and pressure drop correlations for the rectangular offset strip fin compact heat exchanger. Experimental Thermal and Fluid Science 1995;10(2):171-180.

[24] Incropera, F.P., DeWitt, D.P., Bergman, T.L., Lavine, A.S.. Fundamentals of Heat and Mass Transfer. 6 ed.; Jefferson City, United States of America: John Wiley \& Sons, Inc.; 2007. ISBN: 9780470501979.

[25] Kurzke, J.. Component map collection 2, Compressor and turbine maps for gas turbine performance computer programs. www.gasturb.de/ [accessed: 19/09/2013]. Germany; 2004.

[26] Kurzke, J.. How to create a performance model of a gas turbine from a limited amount of information. In: Proceedings of ASME Turbo Expo 2005. Reno-Tahoe, United States of America; 2005, p. 145-153.

[27] Stodola, A.. Dampf- und Gasturbinen: Mit einem Anhang über die Aussichten der Wärmekraftmaschinen. Berlin, Germany: Springer Berlin; 1922. ISBN: 7352997563.

[28] Schobeiri, M.. Turbomachinery flow physics and dynamic performance. Berlin, Germany: Springer Berlin; 2005. ISBN: 9783540223689.

[29] Veres, J.P.. Centrifugal and axial pump design and off-design performance prediction. Tech. Rep.; NASA; Sunnyvale, United States of America; 1994. Technical Memorandum 106745.

[30] Haglind, F., Elmegaard, B.. Methodologies for predicting the part-load performance of aero-derivative gas turbines. Energy 2009;34(10):1484 - 1492.

[31] Casella, F., Mathijssen, T., Colonna, P., van Buijtenen, J.. Dynamic modeling of ORC power systems. Journal of Engineering for Gas Turbines and Power 2012;135:1-12.

[32] Bejan, A., Moran, M.J.. Thermal design and optimization. Hoboken, United States of America: John Wiley \& Sons, Inc.; 1996. ISBN: 9780471584674.

[33] Valero, A., Lozano, M.A., Serra, L., Tsatsaronis, G., Pisa, J., Frangopoulos, C., et al. CGAM problem: definition and conventional solution. Energy 1994;19(3):279-286.

[34] Lozano, M.A., Valero, A., Serra, L.. Theory of exergetic cost and thermoeconomic optimization. In: Proceedings of the International Symposium ENSEC. Cracow, Poland; 1993, p. 339 - 350.

[35] Lian, Z., Chua, K., Chou, S.. A thermoeconomic analysis of biomass energy for trigeneration. Applied Energy 2010;87(1):84-95.

[36] Hall, S., Ahmad, S., Smith, R.. Capital cost targets for heat exchanger networks comprising mixed materials of construction, pressure ratings and exchanger types. Computers \& chemical engineering 1990;14(3):319-335.

[37] Genceli, O.. Heat exchangers. Turkey: Birsen Book Company; 1999. ISBN: 9789755112183.

[38] Astolfi, M., Romano, M.C., Bombarda, P., Macchi, E.. Binary ORC (Organic Rankine Cycles) power plants for the exploitation of medium-low temperature geothermal sources-Part B: Techno-economic optimization. 
Energy 2014;66:435-446.

2 [39] Inflationdata web site, . inflationdata.com/Inflation. [accessed: 10/05/2014].

3 [40] Pierobon, L., Casati, E., Casella, F., Haglind, F., Colonna, P.. Design methodology for flexible energy conversion systems accounting for dynamic performance. Energy 2014;68:667-679.

5 [41] Deb, K.. Multi-objective optimization using evolutionary algorithms. West Sussex, Great Britain: John Wiley \& Sons, Inc.; 2001. ISBN: 9780470743614.

7 [42] Bonacina, C., Cavallini, A., Mattarolo, L.. Trasmissione del calore. Padova, Italy: Cleup; 1992. ISBN: 9788871789200.

9 [43] Boyce, M.P.. Gas turbine engineering handbook. Oxford, Great Britain: Butterworth-Heinemann; 2012. ISBN: 9780123838421.

[44] Pierobon, L., Haglind, F., Kandepu, R., Fermi, A., Rossetti, N.. Technologies for waste heat recovery in off-shore applications. In: Proceedings of ASME 2013 International Mechanical Engineering Congress \& Exposition. San Diego, California; 2013, p. 1-10.

[45] Quoilin, S., Broek, M.V.D., Declaye, S., Dewallef, P., Lemort, V.. Techno-economic survey of organic Rankine cycle (ORC) systems. Renewable and Sustainable Energy Reviews 2013;22:168-186. 


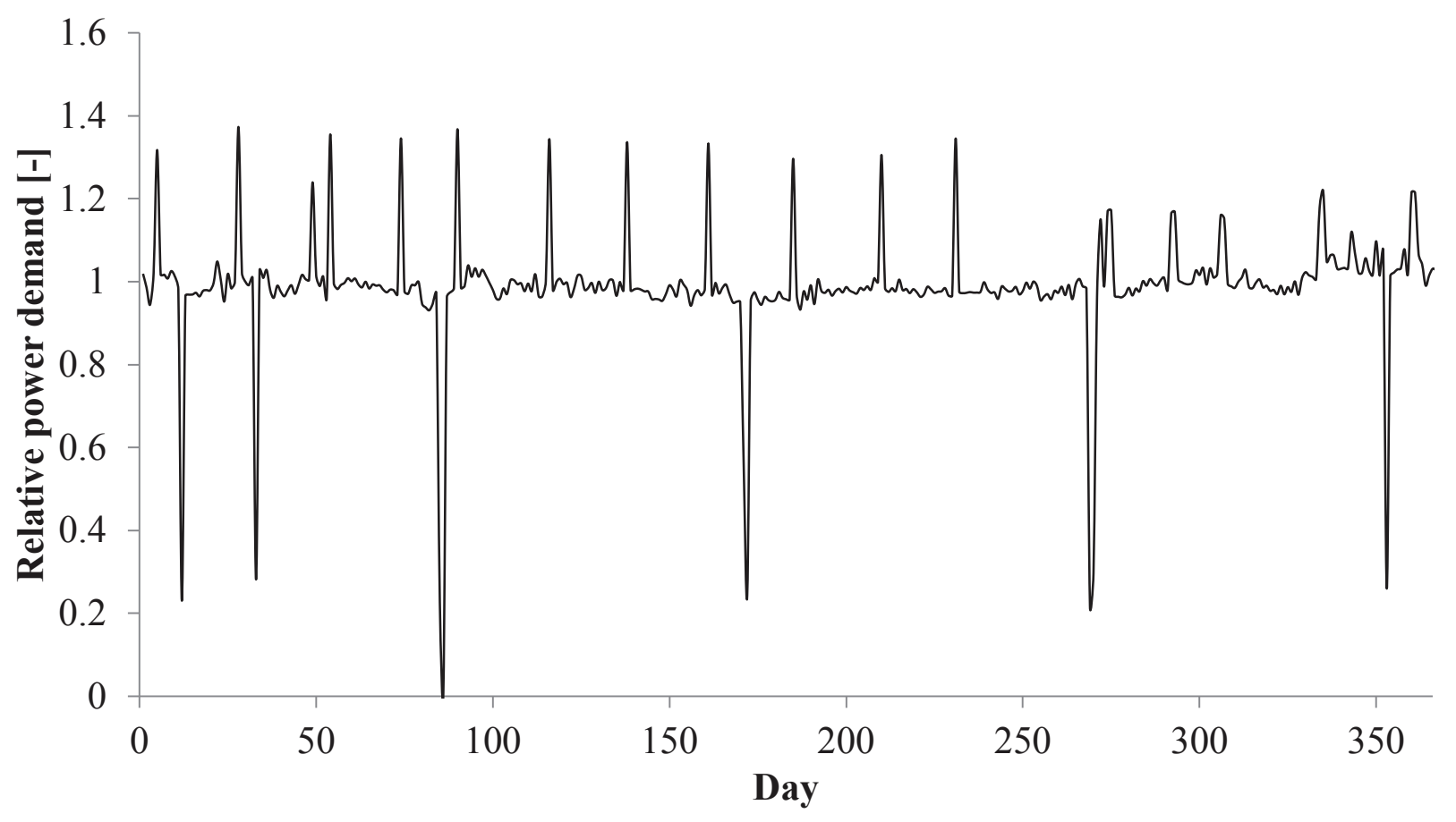

Figure 1: Relative electric power demand on the Draugen offshore oil and gas platform in 2012. Daily average values are reported. 

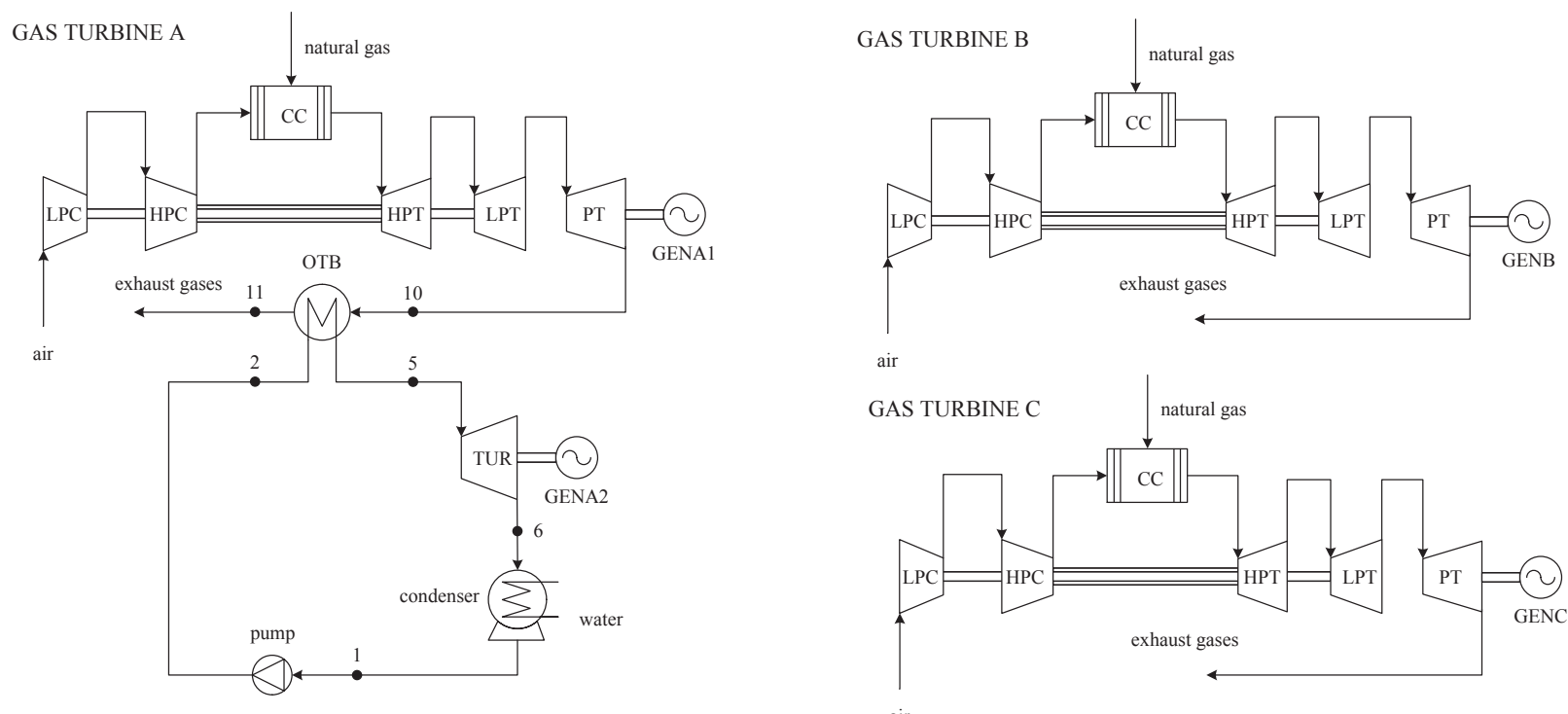

Figure 2: Simplified layout of the power system on the Draugen offshore oil and gas platform. The steam Rankine cycle module is added to recover part of the thermal power released with the exhaust gases of one engine, in the case gas turbine A. 


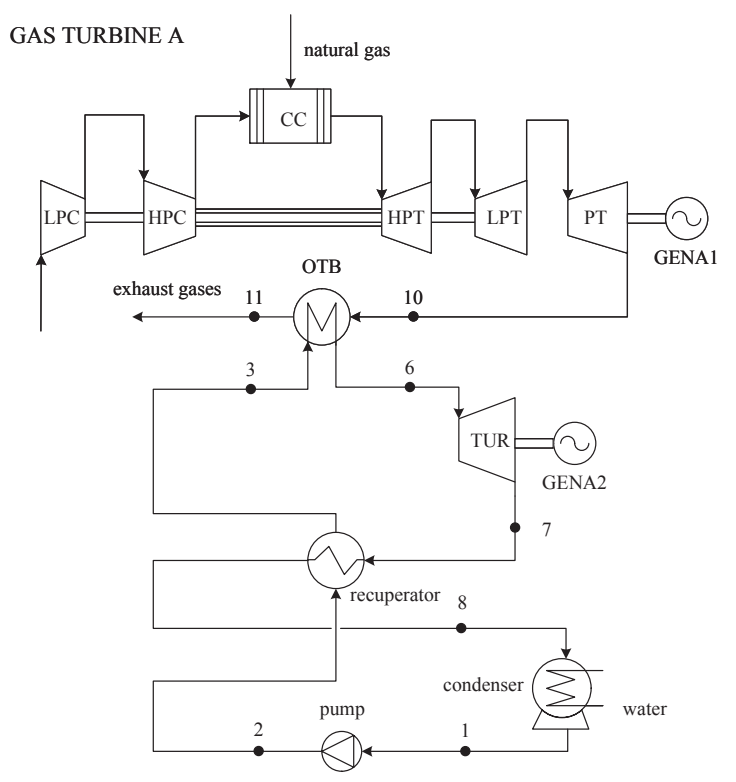

(a)

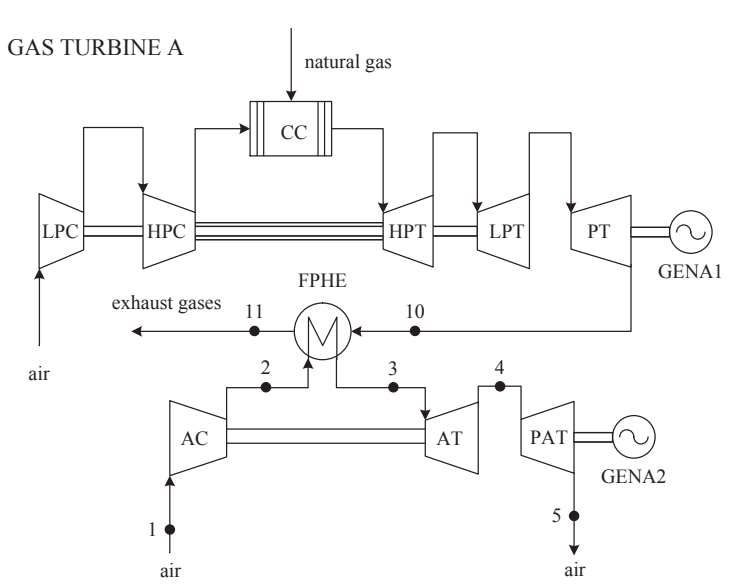

(b)

Figure 3: Combined cycle layouts, gas turbines $\mathrm{B}$ and $\mathrm{C}$ are also available but they are not shown in the sub-figures. 3(a) The organic Rankine cycle unit recovers part of the thermal power released with the exhausts of turbine A. 3(b) The air bottoming cycle module recuperates part of the thermal power released with the exhausts of turbine A. 


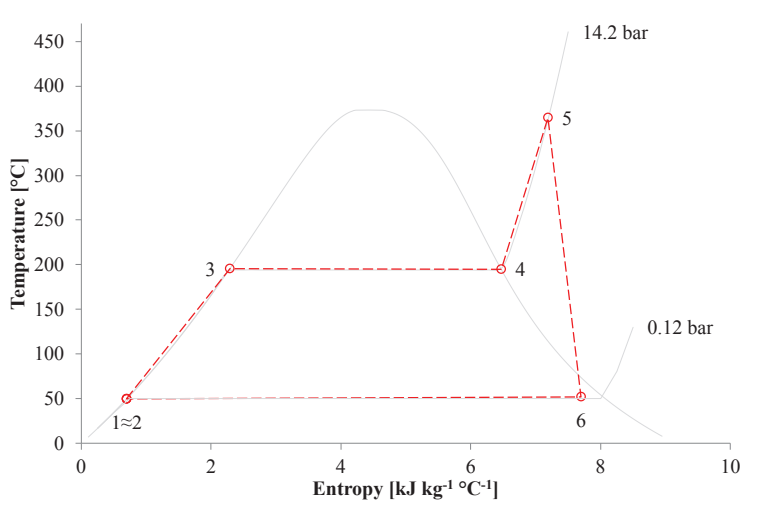

(a)

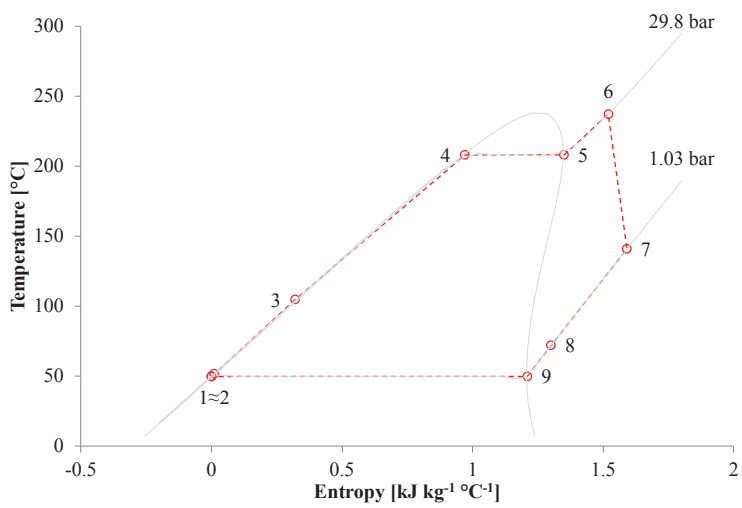

(b)

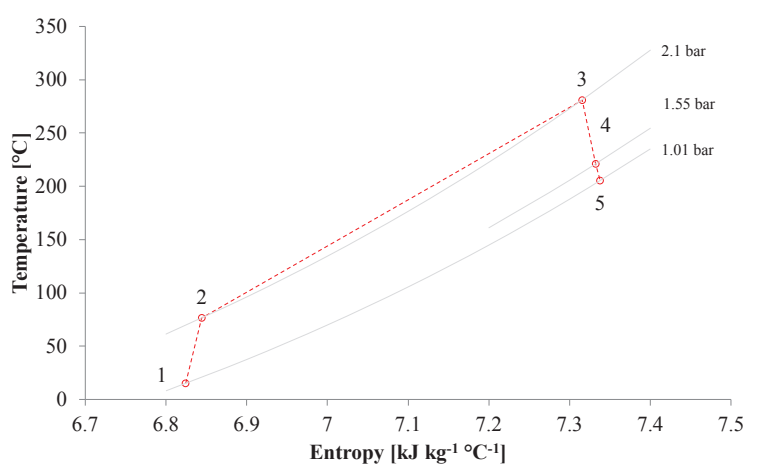

(c)

Figure 4: $T-s$ diagrams showing the thermodynamic cycle state points of one design candidate for each waste heat recovery technology. Isobar lines are also reported, pressure drops are neglected. 4(a) $T-s$ diagram and saturation dome (water) for the SRC turbogenerator. 4(b) $T-s$ diagram and saturation dome (cyclopentane) for the ORC power module. 4(c) $T-s$ diagram for the ABC unit. 


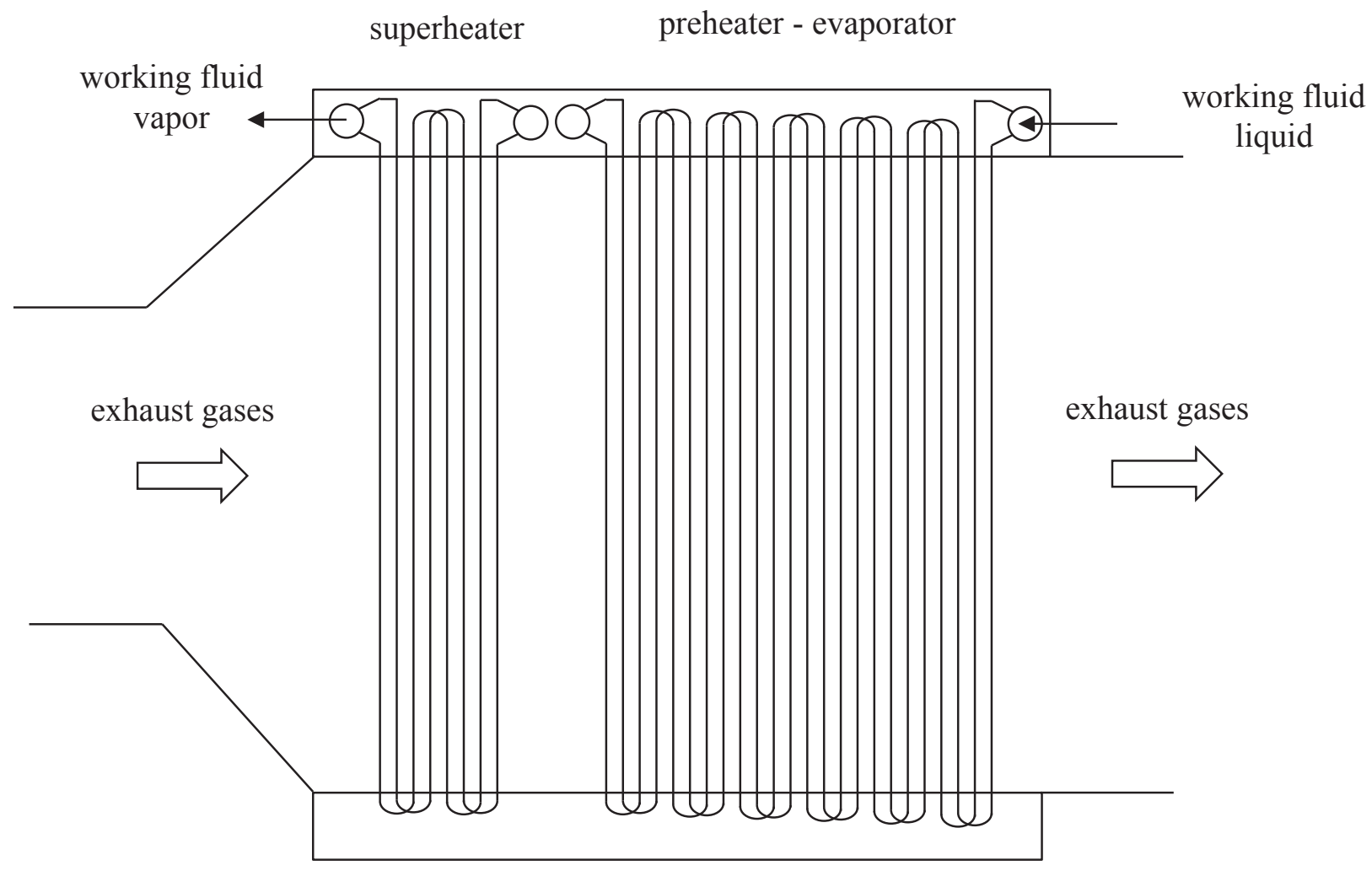

Figure 5: Layout of the once-through boiler serving the steam Rankine cycle and the organic Rankine cycle power units. The exhaust gases exiting the gas turbine heat up the working fluid (water or cyclopentane) which circulates first inside the preheater-evaporator, and, subsequently, in the superheater. 


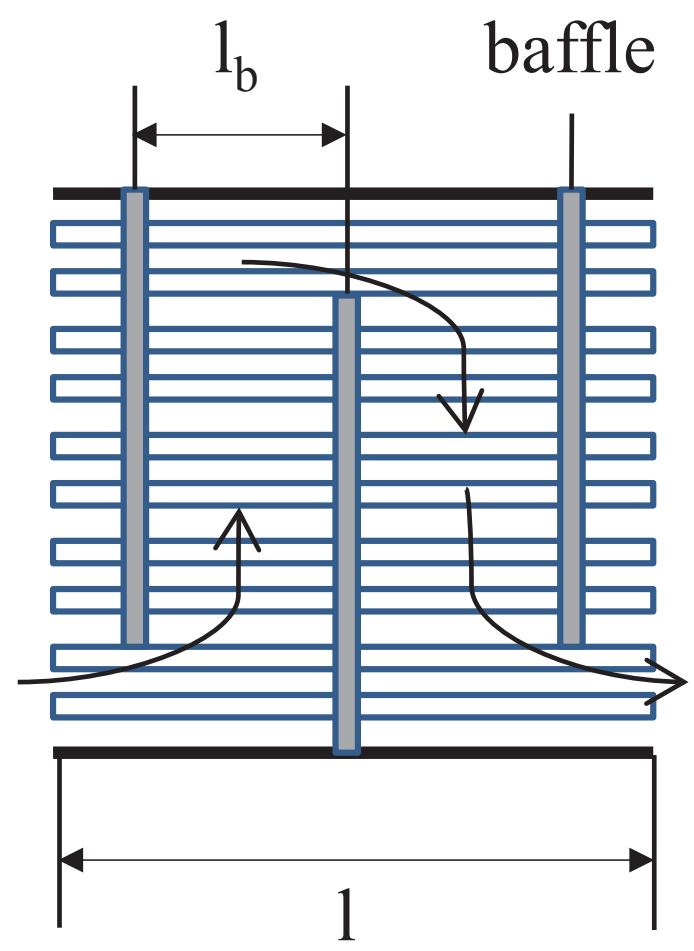

(a)
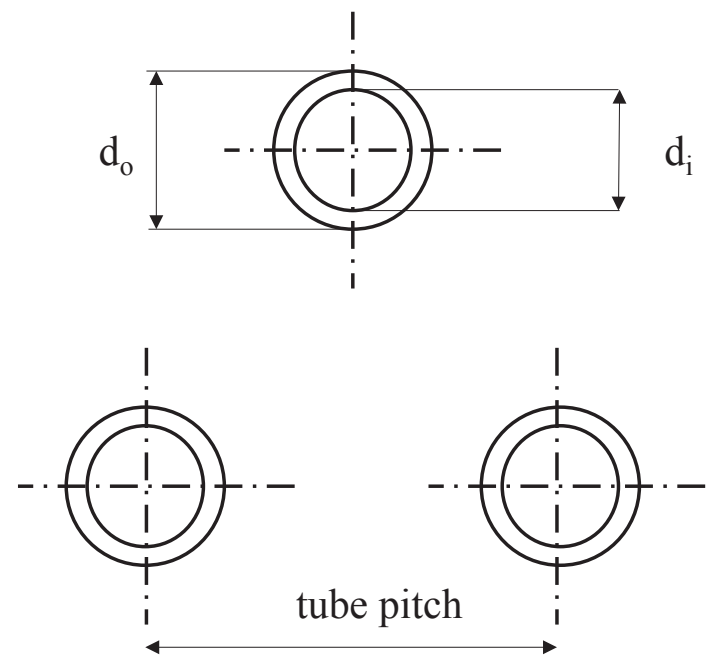

(b)

Figure 6: Layout of the shell-and-tube heat exchanger used for the condensation process and as recuperator in the organic Rankine cycle module. 6(a) Tube arrangement and shell flow pattern. 6(b) Triangular tube pattern. 


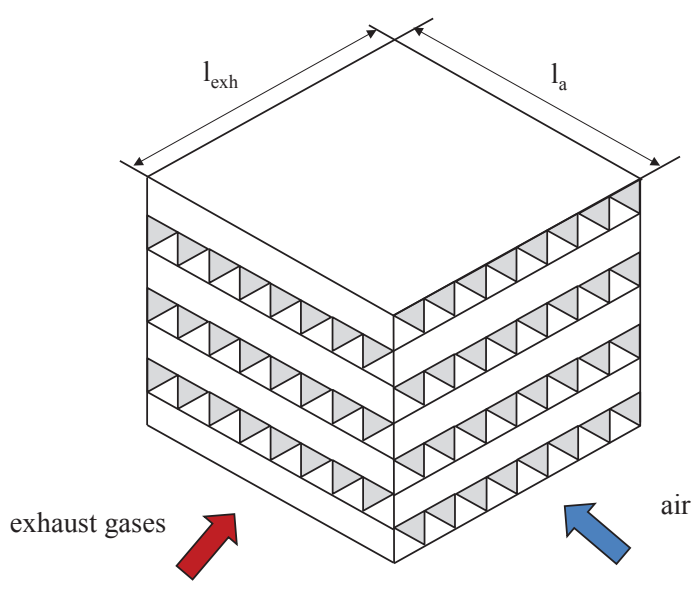

(a)

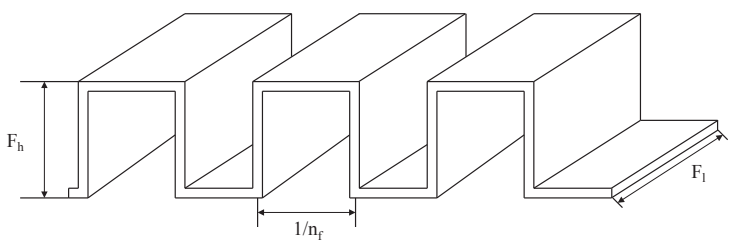

(b)

Figure 7: Layout of the finned-plate heat exchanger serving the air bottoming cycle power unit. 7(a) Exhaust gas and air flow pattern. 7(b) Finned-plate pattern. 


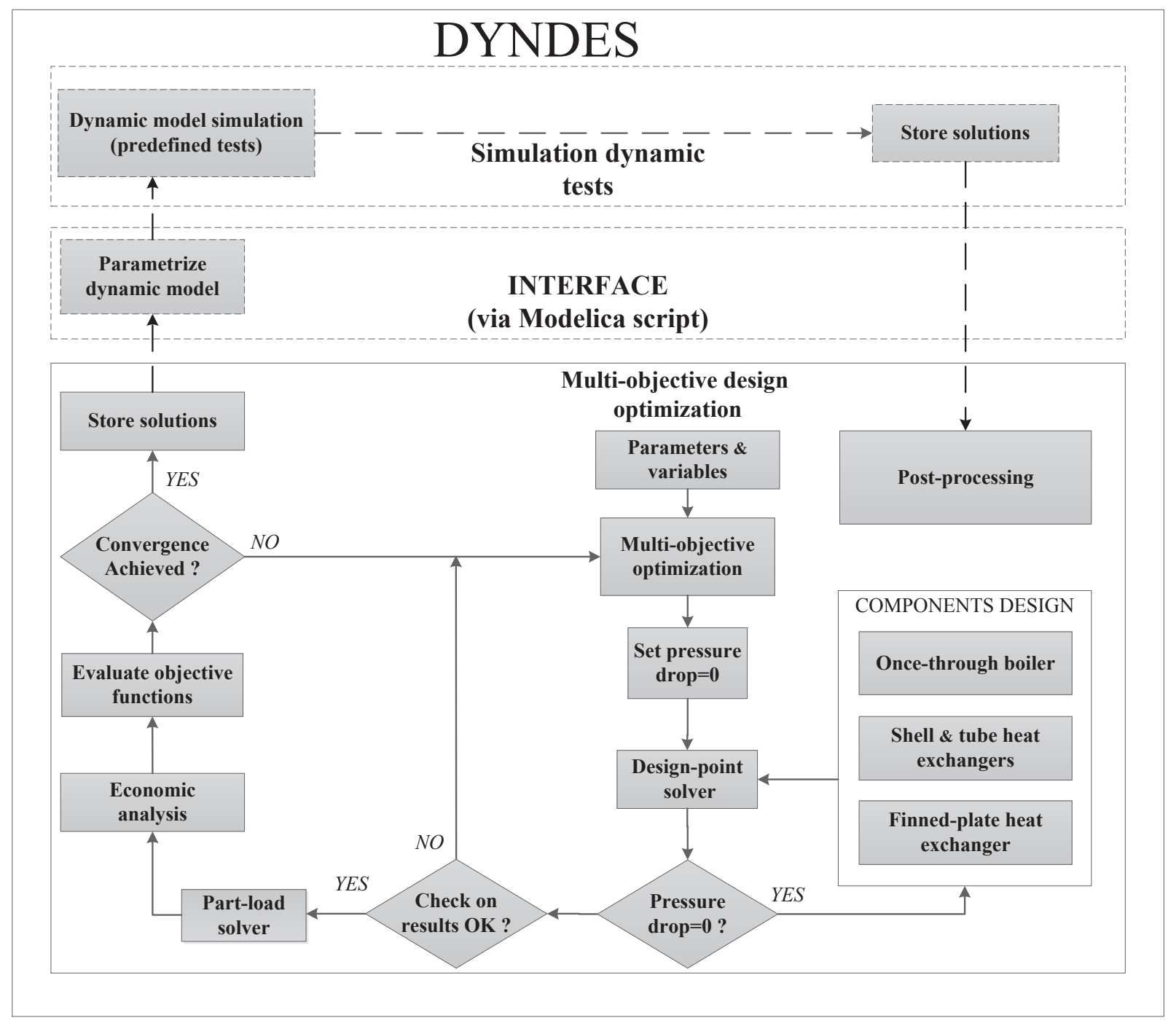

Figure 8: Architecture of the DYNDES design tool. The usage of the program is limited to the steady-state designpoint optimization. 


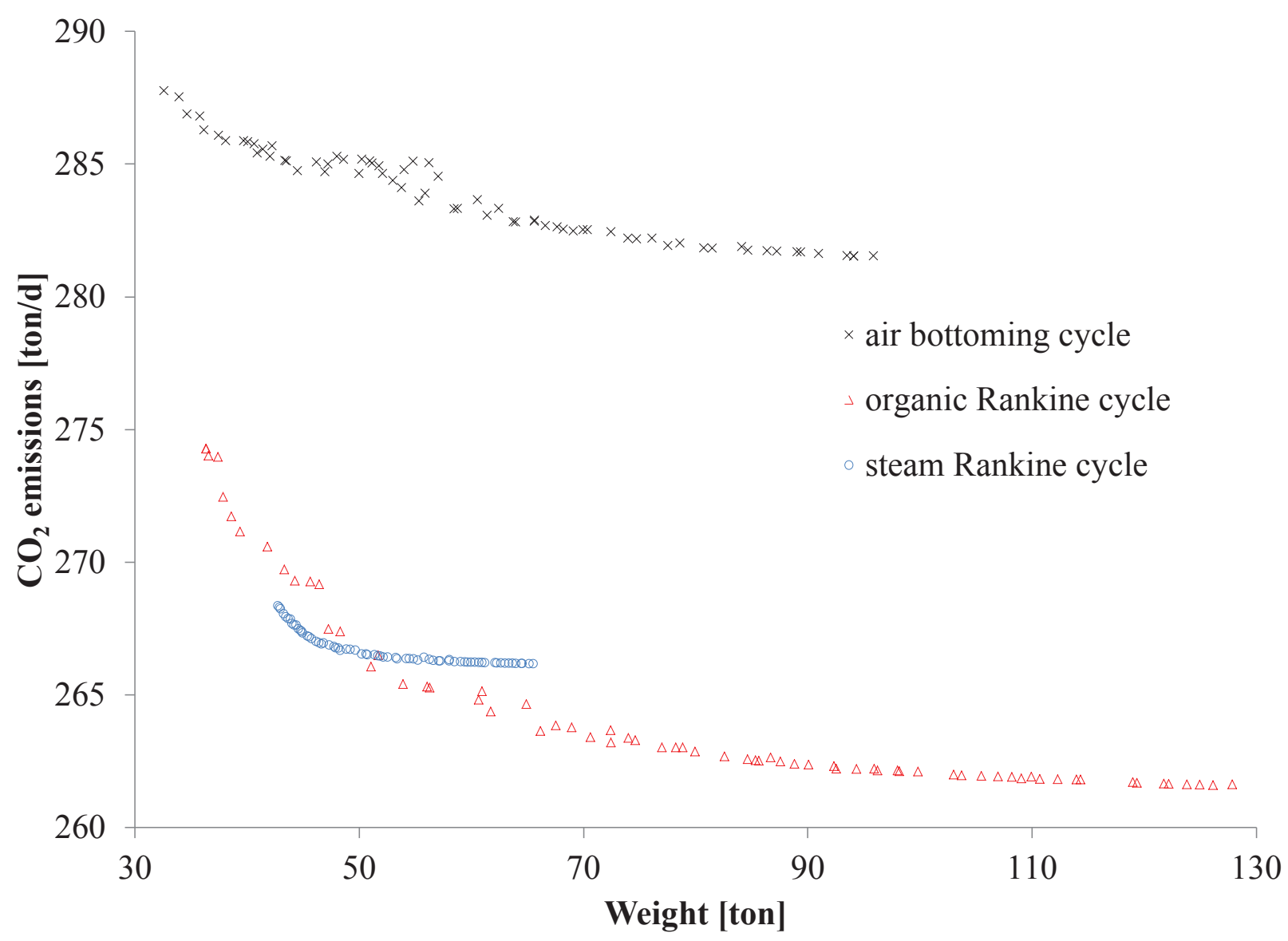

Figure 9: Pareto fronts of the three waste heat recovery technologies. The $\mathrm{CO}_{2}$ emissions (first objective function) are given as a function of the weight of the bottoming cycle units (second objective function). 


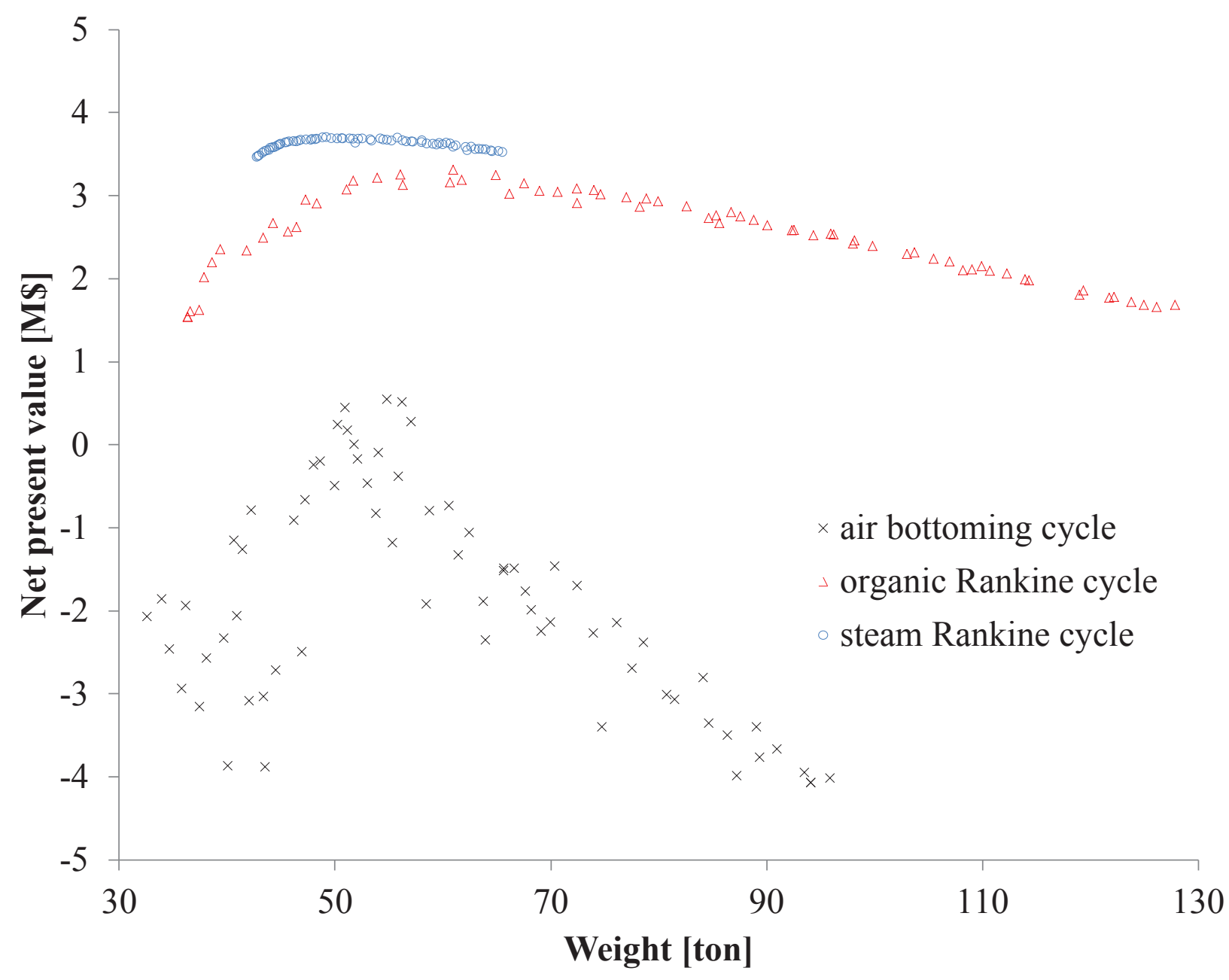

Figure 10: Pareto fronts of the three waste heat recovery technologies. The net present value (third objective function) is related to the weight of the bottoming cycle units. 


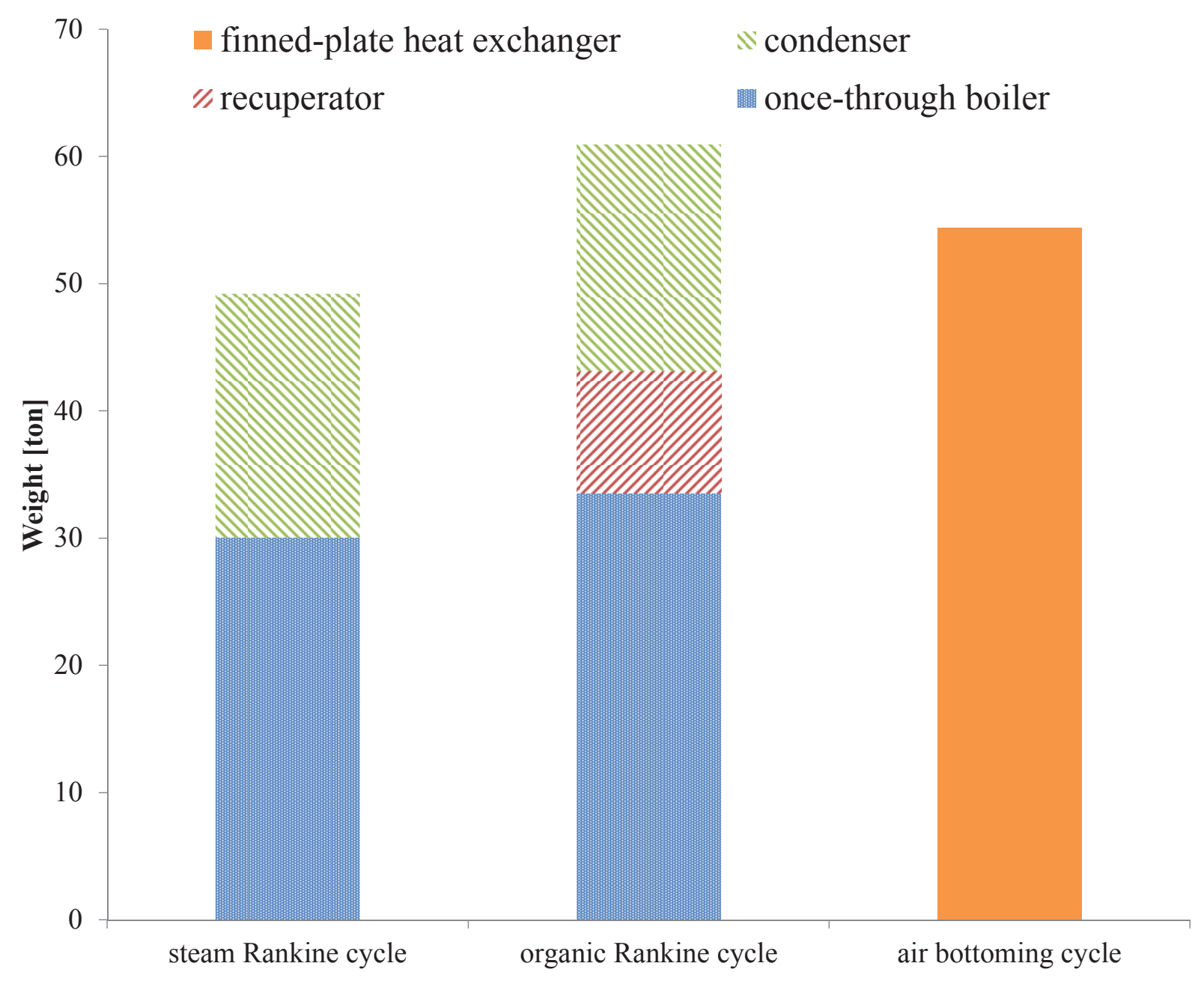

Figure 11: Breakdown of the weight for the three waste heat recovery technologies. The weight of the heat exchangers constituting the bottoming cycle units is reported. 


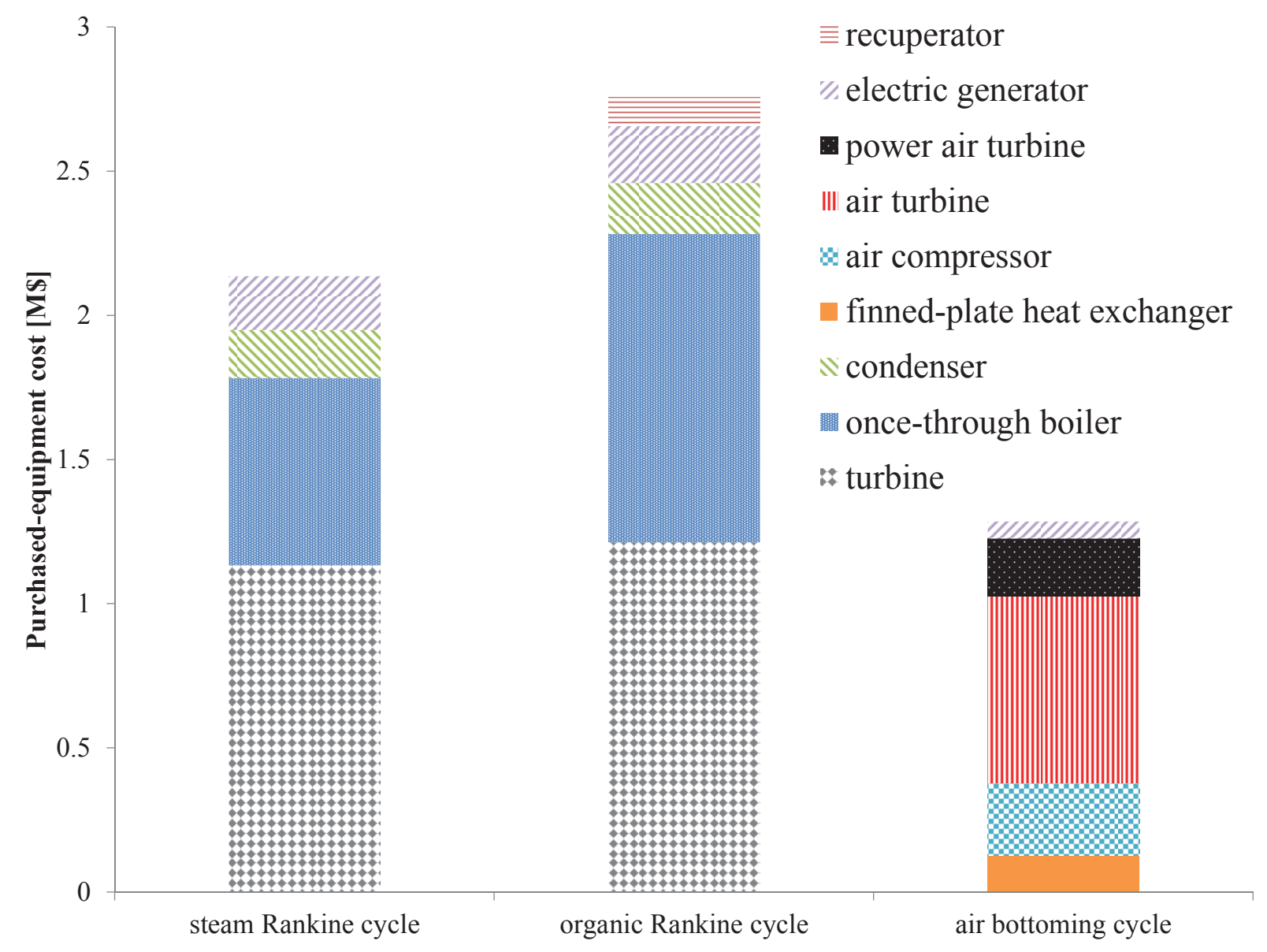

Figure 12: Breakdown of the purchased-equipment cost for the three waste heat recovery technologies. The purchased-equipment cost of the components constituting the bottoming cycle units is indicated. 
Table 1: Design-point specifications for the twin-spool gas turbine installed on the Draugen offshore oil and gas platform.

\begin{tabular}{lr}
\hline Model & Siemens SGT500 \\
\hline Turbine inlet temperature & $850^{\circ} \mathrm{C}$ \\
Exhaust gas temperature $t_{10}$ & $379.2^{\circ} \mathrm{C}$ \\
Exhaust gas mass flow $\dot{m}_{10}$ & $91.5 \mathrm{~kg} / \mathrm{s}$ \\
Electric power output & $16.5 \mathrm{MW}$ \\
Thermal efficiency & $31.3 \%$ \\
Fuel & Natural gas \\
\hline
\end{tabular}


Table 2: Breakdown of the total capital investment.

\begin{tabular}{lr}
\hline Total capital investment & \\
\hline I. Fixed-capital investment (FCI) & \\
A. Direct costs & \\
Purchased - equipment costs (PEC) & $15 \%$ PEC \\
Purchased - equipment installation & $35 \%$ PEC \\
Piping & $12 \%$ PEC \\
Instrumentation and controls & $13 \%$ PEC \\
Electrical equipment and materials & \\
B. Indirect costs & $4 \% \mathrm{DC}$ \\
a) Engineering and supervision & $15 \% \mathrm{DC}$ \\
b) Construction costs and contractor's profit & \\
Contingencies & $4 \%$ FCI \\
II. Other outlays & $15 \% \mathrm{TCI}$ \\
Startup costs & $7.5 \% \mathrm{FCI}$ \\
Working capital & $7.5 \% \mathrm{FCI}$ \\
Costs of licensing, research and development & Allowance for funds used during construction \\
\hline
\end{tabular}


Table 3: Price index and index factors for the calculation of the purchased-equipment costs. The reference price index is 233.916 (2014).

\begin{tabular}{lccc}
\hline Source year & Component & Price index & Index factor \\
\hline 1993 & $\begin{array}{c}\text { steam turbine, } \\
\text { SRC and ORC pumps } \\
\text { once-through boiler, }\end{array}$ & 142.6 & 1.64 \\
1994 & 146.2 & 1.60 \\
1999 & $\begin{array}{c}\text { ABC compressor and turbines } \\
\text { finned-plate heat exchanger }\end{array}$ & 164.3 & 1.42 \\
1988 & shell-and-tube heat exchangers & 115.7 & 2.02 \\
2010 & $\begin{array}{c}\text { electric generators } \\
2014\end{array}$ & 216.687 & 1.08 \\
ORC turbine & 233.916 & 1.00 \\
\hline
\end{tabular}


Table 4: Lower and upper bound for the variables involved in the multi-objective optimization of the three power systems described in Section 2.

\begin{tabular}{lcc}
\hline Variable & Lower bound & Upper bound \\
\hline Turbine inlet pressure [bar] & 5 & 41.1 \\
Pinch point recuperator $\left[{ }^{\circ} \mathrm{C}\right]$ & 10 & 40 \\
Temperature difference OTB $\left[{ }^{\circ} \mathrm{C}\right]$ & 10 & 80 \\
Pinch point condenser $\left[{ }^{\circ} \mathrm{C}\right]$ & 10 & 40 \\
Temperature difference $\mathrm{FPHE}\left[{ }^{\circ} \mathrm{C}\right]$ & 10 & 150 \\
Exhaust gas temperature $\left[{ }^{\circ} \mathrm{C}\right]$ & 140 & 180 \\
Inner diameter of the tubes [mm] & 16 & 50 \\
Length of the tubes [m] & 1.83 & 7.32 \\
Number of parallel tubes [-] & 1 & 100 \\
Baffle spacing [\%] & 20 & 120 \\
Pressure ratio [-] & 1.5 & 5 \\
Fin height (FPHE) [mm] & 2 & 50 \\
Fin frequency (FPHE) [m $\left.{ }^{-1}\right]$ & 100 & 1000 \\
Fin length (FPHE) [mm] & 3 & 150 \\
Number of plates (FPHE) $[-]$ & 1 & 200 \\
Flow length gas side (FPHE) [m] & 1.2 & 3 \\
\hline
\end{tabular}


Table 5: Parameters assumed for the multi-objective optimization.

\begin{tabular}{|c|c|}
\hline Parameter & Value \\
\hline Electric efficiency of the generators [\%] & 98 \\
\hline Ambient temperature $\left[{ }^{\circ} \mathrm{C}\right]$ & 15 \\
\hline Ambient pressure [bar] & 1.032 \\
\hline \multicolumn{2}{|l|}{ Steam Rankine cycle } \\
\hline Pump isentropic efficiency [\%] & 80 \\
\hline Turbine isentropic efficiency [\%] & 80 \\
\hline Condensing pressure [bar] & 0.12 \\
\hline \multicolumn{2}{|l|}{ Organic Rankine cycle } \\
\hline Working fluid & cyclopentane \\
\hline Pump isentropic efficiency [\%] & 72 \\
\hline Turbine isentropic efficiency [\%] & 80 \\
\hline Condensing pressure [bar] & 1.03 \\
\hline \multicolumn{2}{|l|}{ Air bottoming cycle } \\
\hline Air compressor isentropic efficiency [\%] & 88 \\
\hline Air turbines isentropic efficiency [\%] & 90 \\
\hline \multicolumn{2}{|l|}{ Once-through boiler } \\
\hline Layout & in-line \\
\hline Material & Stainless steel \\
\hline Tubes thickness [mm] & 3.0 \\
\hline Longitudinal pitch [mm] & 83 \\
\hline Transversal pitch [mm] & 83 \\
\hline Fin pitch $[\mathrm{mm}]$ & 4 \\
\hline Fin height $[\mathrm{mm}]$ & 15 \\
\hline Fin thickness $[\mathrm{mm}]$ & 0.4 \\
\hline Fin efficiency [\%] & 90 \\
\hline \multicolumn{2}{|l|}{ Recuperator } \\
\hline Layout & triangular pitch \\
\hline Material & Cupro-nickel \\
\hline Tube pitch [-] & 1.25 \\
\hline Tubes thickness [mm] & 3.0 \\
\hline Fin pitch [mm] & 4 \\
\hline Fin height [mm] & 15 \\
\hline Fin thickness $[\mathrm{mm}]$ & 0.4 \\
\hline Fin efficiency [\%] & 90 \\
\hline \multicolumn{2}{|l|}{ Condenser } \\
\hline Layout & triangular pitch \\
\hline Material & Stainless steel \\
\hline Temperature cooling water $\left[{ }^{\circ} \mathrm{C}\right]$ & 5 \\
\hline Tube pitch [-] & 1.4 \\
\hline Tubes thickness [mm] & 3.0 \\
\hline \multicolumn{2}{|l|}{ Finned-plate heat exchanger } \\
\hline Material & Stainless steel \\
\hline Fin thickness $[\mathrm{mm}]$ & 1 \\
\hline Plate thickness [mm] & 1 \\
\hline
\end{tabular}


Table 6: Results of the multi-objective optimization. Maximum, minimum, arithmetic mean average, and relative standard deviation of the optimized variables. The values are acquired from the Pareto fronts of the waste heat recovery systems.

\begin{tabular}{|c|c|c|c|c|}
\hline Variable & Maximum & Minimum & AMA & RSD [\%] \\
\hline \multicolumn{5}{|c|}{ Steam Rankine cycle } \\
\hline$p_{5}[\mathrm{bar}]$ & 14.3 & 14.1 & 14.2 & 0.35 \\
\hline$\Delta T_{\text {Отв }}\left[{ }^{\circ} \mathrm{C}\right]$ & 24.9 & 22.7 & 23.3 & 2.60 \\
\hline$T_{11}\left[{ }^{\circ} \mathrm{C}\right]$ & 176.2 & 176.0 & 176.1 & 0.03 \\
\hline$\Delta T_{\mathrm{c}}\left[{ }^{\circ} \mathrm{C}\right]$ & 30.1 & 28.4 & 29.8 & 1.57 \\
\hline$d_{\mathrm{i}, \text { OTB }}[\mathrm{mm}]$ & 27.1 & 17.0 & 22.3 & 14.50 \\
\hline$d_{\mathrm{i}, \text { OTB,sup }}[\mathrm{mm}]$ & 45.7 & 34.5 & 40.0 & 8.57 \\
\hline$l_{\text {Отв }}[\mathrm{m}]$ & 3.2 & 2.8 & 2.9 & 4.12 \\
\hline$N t_{\text {Отв }}[-]$ & 74 & 63 & 67 & 6.39 \\
\hline$d_{\mathrm{i}, \mathrm{c}}[\mathrm{mm}]$ & 49.9 & 42.2 & 45.3 & 6.20 \\
\hline$l_{\mathrm{c}}[\mathrm{m}]$ & 4.9 & 4.8 & 4.9 & 0.61 \\
\hline$l_{\mathrm{b}, \mathrm{c}}[\%]$ & 117.7 & 117.6 & 117.7 & 0.03 \\
\hline \multicolumn{5}{|c|}{ Organic Rankine cycle } \\
\hline$p_{6}[\mathrm{bar}]$ & 39.6 & 32.5 & 38.1 & 6.00 \\
\hline$\Delta T_{\text {Отв }}\left[{ }^{\circ} \mathrm{C}\right]$ & 64.7 & 32.1 & 47.9 & 23.28 \\
\hline$\Delta T_{\mathrm{r}}\left[{ }^{\circ} \mathrm{C}\right]$ & 38.5 & 24.2 & 27.3 & 18.93 \\
\hline$T_{11}\left[{ }^{\circ} \mathrm{C}\right]$ & 174.2 & 158.4 & 162.3 & 3.54 \\
\hline$\Delta T_{\mathrm{c}}\left[{ }^{\circ} \mathrm{C}\right]$ & 37.3 & 34.5 & 35.3 & 1.47 \\
\hline$d_{\mathrm{i}, \text { OTB }}[\mathrm{mm}]$ & 46.5 & 31.6 & 41.4 & 10.44 \\
\hline$d_{\mathrm{i}, \text { OTB,sup }}[\mathrm{mm}]$ & 46.7 & 36.4 & 44.3 & 5.38 \\
\hline$l_{\mathrm{OTB}}[\mathrm{m}]$ & 3.6 & 1.9 & 2.8 & 16.02 \\
\hline$N t_{\text {Отв }}[-]$ & 47 & 40 & 45 & 5.97 \\
\hline$d_{\mathrm{i}, \mathrm{r}}[\mathrm{m}]$ & 34.5 & 24.3 & 29.2 & 5.53 \\
\hline$l_{\mathrm{r}}[\mathrm{m}]$ & 6.0 & 5.0 & 5.2 & 5.70 \\
\hline$l_{\mathrm{b}, \mathrm{r}}[\%]$ & 75.2 & 69.5 & 73.6 & 2.83 \\
\hline$d_{\mathrm{i}, \mathrm{c}}[\mathrm{m}]$ & 49.7 & 23.0 & 37.8 & 22.58 \\
\hline$l_{\mathrm{c}}[\mathrm{m}]$ & 7.1 & 5.2 & 5.7 & 10.54 \\
\hline$l_{\mathrm{b}, \mathrm{c}}[\%]$ & 76.5 & 74.2 & 74.8 & 0.62 \\
\hline \multicolumn{5}{|c|}{ Air bottoming cycle } \\
\hline$r_{\mathrm{c}}[-]$ & 2.9 & 2.0 & 2.4 & 11.22 \\
\hline$\Delta T_{\mathrm{FPHE}}\left[{ }^{\circ} \mathrm{C}\right]$ & 116.8 & 71.6 & 87.8 & 15.68 \\
\hline$T_{11}\left[{ }^{\circ} \mathrm{C}\right]$ & 164.0 & 163.5 & 163.7 & 0.07 \\
\hline$F_{\mathrm{h}, \mathrm{a}}[\mathrm{mm}]$ & 38.2 & 22.0 & 31.1 & 13.22 \\
\hline$n f_{\mathrm{a}}\left[\mathrm{m}^{-1}\right]$ & 246.7 & 229.5 & 237.3 & 1.82 \\
\hline$F_{1, \mathrm{a}}[\mathrm{mm}]$ & 146.0 & 28.8 & 77.0 & 41.73 \\
\hline$F_{\mathrm{h}, \mathrm{exh}}[\mathrm{mm}]$ & 39.9 & 34.2 & 38.0 & 2.85 \\
\hline$n f_{\mathrm{exh}}\left[\mathrm{m}^{-1}\right]$ & 226 & 203 & 214 & 3.48 \\
\hline$F_{1, \text { exh }}[\mathrm{mm}]$ & 133.7 & 97.0 & 120.5 & 5.60 \\
\hline$N p_{\text {exh }}[-]$ & 152.7 & 142.1 & 148.1 & 2.05 \\
\hline$l_{\mathrm{exh}}[\mathrm{m}]$ & 2.7 & 1.8 & 2.2 & 11.87 \\
\hline
\end{tabular}

